The Cryosphere Discuss., doi:10.5194/tc-2016-263, 2016

Manuscript under review for journal The Cryosphere

Published: 17 November 2016

(c) Author(s) 2016. CC-BY 3.0 License.

\title{
Archival of the water stable isotope signal in East Antarctic ice cores
}

\author{
Mathieu Casado ${ }^{1,2}$, Amaelle Landais ${ }^{1}$, Ghislain Picard ${ }^{3}$, Thomas Münch ${ }^{4,5}$, Thomas Laepple ${ }^{4}$, \\ Barbara Stenni ${ }^{6}$, Giuliano Dreossi ${ }^{6}$, Alexey Ekaykin ${ }^{7}$, Laurent Arnaud ${ }^{3}$, Christophe Genthon ${ }^{3}$, \\ Alexandra Touzeau ${ }^{1}$, Valerie Masson-Delmotte ${ }^{1}$, and Jean Jouzel ${ }^{1}$ \\ ${ }^{1}$ Laboratoire des Sciences du Climat et de l'Environnement - IPSL, UMR 8212, CEA-CNRS-UVSQ, Gif sur Yvette, France \\ ${ }^{2}$ Université Grenoble Alpes / CNRS, LIPHY, F-38000 Grenoble, France \\ ${ }^{3}$ Université Grenoble Alpes / CNRS, LGGE, 38400 Grenoble, France \\ ${ }^{4}$ Alfred Wegener Institute Helmholtz Centre for Polar and Marine Research, Telegrafenberg A43, 14473 Potsdam, Germany \\ ${ }^{5}$ Institute of Physics and Astronomy, University of Potsdam, Karl-Liebknecht-Str. 24/25, 14476 Potsdam, Germany \\ ${ }^{6}$ DAIS, Ca'Foscari University of Venice, Venice, Italy \\ ${ }^{7}$ Arctic and Antarctic Research Institute, St. Petersburg, Russia \\ Correspondence to: Mathieu Casado (mathieu.casado@gmail.com)
}

\begin{abstract}
The oldest ice core records are obtained from the East Antarctic plateau. Water stable isotopes records are key for reconstructions of past climatic conditions both over the ice sheet and at the evaporation source. The accuracy of such climate reconstructions crucially depends on the knowledge of all the processes affecting the water vapour, precipitation and snow isotopic composition. Atmospheric fractionation processes are well understood and can be integrated in Rayleigh distillation and complex isotope enabled climate models. However, a comprehensive quantitative understanding of processes potentially altering the snow isotopic composition after the deposition is still missing, especially for exchanges between vapour and snow. In low accumulation sites such as found on the East Antarctic Plateau, these poorly constrained processes are especially likely to play a significant role. This limits the interpretation of isotopic composition from ice core records, specifically at short time scales.
\end{abstract}

Here, we combine observations of isotopic composition in the vapour, the precipitation, the surface snow and the buried snow from various sites of the East Antarctic Plateau. At the seasonal scale, we highlight a significant impact of metamorphism on surface snow isotopic signal compared to the initial precipitation isotopic signal. In particular, in summer, exchanges of water molecules between vapour and snow are driven by the sublimation/condensation cycles at the diurnal scale. Using highly resolved isotopic composition profiles from pits in five East Antarctic sites, we identify a common $20 \mathrm{~cm}$ cycle which cannot be attributed to the seasonal variability of precipitation. Altogether, the smaller range of isotopic compositions observed in the buried and in the surface snow compared to the precipitation, and also the reduced slope between surface snow isotopic composition and temperature compared to precipitation, constitute evidences of post-deposition processes affecting the variability of the isotopic composition in the snow pack. To reproduce these processes in snow-models is crucial to understand the link between snow isotopic composition and climatic conditions and to improve the interpretation of isotopic composition as a paleoclimate proxy. 
The Cryosphere Discuss., doi:10.5194/tc-2016-263, 2016

Manuscript under review for journal The Cryosphere

Published: 17 November 2016

(c) Author(s) 2016. CC-BY 3.0 License.

\section{Introduction}

Ice is a natural archive of past climate variations. The chemical and physical compositions of the ice and of the air bubbles trapped inside are used as paleoclimate proxies (Jouzel and Masson-Delmotte, 2010). In Greenland, ice cores provide reconstructions of past temperature from greenhouse gas concentrations and water isotopes back to the last interglacial period, 120 000 years ago (North Greenland Ice Core Project members, 2004; NEEM community members, 2013). In Antarctica, low accumulation rates enable the reconstruction of past climate over several interglacial periods, e.g. 420000 years at Vostok (Petit et al., 1999) and 800000 years at Dome C (EPICA, 2004, 2006). Even though reconstructions from ice cores from Greenland do not extend as far back as from Antarctic's ice cores, high resolution analyses of the cores from Greenland provide very fine temporal resolution and can even resolve the seasonal cycle (Vinther et al., 2010). Seasonal variations are also imprinted in the snow isotopic composition of high accumulation sites of coastal areas of Antarctica (Morgan, 1985; Masson-Delmotte et al., 2003; Küttel et al., 2012). For low accumulation sites as found on the East Antarctic Plateau, there is no consensus whether ice core records can reveal the climatic signal at resolutions finer than multidecadal (Baroni et al., 2011) or not (Ekaykin et al., 2002; Pol et al., 2014). Ekaykin et al. (2002) analysed multiple pits from Vostok and identified large spatio-temporal variations caused by post-deposition associated with surface topography and wind interactions. These non-climatic phenomena creates high frequency signal in single cores, which calls for stacking isotopic composition profiles from several snow pits to distinguish the common climatic signal from this post-deposition noise. Still, on the East Antarctic Plateau, a significant seasonal cycle is depicted in the isotopic composition of the precipitation (Fujita and Abe, 2006; Landais et al., 2012; Stenni et al., 2016) and of the surface snow (Touzeau et al., 2016). So far, whether this seasonal cycle is archived or not in buried snow, and thus, whether stacking an array of snow pits permits to increase the signal to noise ratio and depict a climatic record at the seasonal scale from water isotopic signal remain unclear (Ekaykin et al., 2014; Altnau et al., 2015; Münch et al., 2016).

Several studies have focused on understanding how is the climatic signal archived in the isotopic composition of snow and ice on the East Antarctic Plateau. Since the early works of Dansgaard (1964) and Lorius et al. (1969), the relationship between ice isotopic composition and local temperature has been attributed to the distillation associated with the successive condensation events on the path from the initial evaporation site to the deposition site. Nevertheless, the relationship between isotopic composition and surface temperature is not constant through time and space, due notably to processes within the boundary layer (Krinner et al., 1997), the seasonality of the precipitation between glacial and interglacial periods (Sime et al., 2009), variations in the air masses transport trajectories (Delaygue et al., 2000; Schlosser et al., 2004) and evaporation conditions (Vimeux et al., 1999). For Central East Antarctica, the glacial-interglacial isotope-temperature relationship appears quite close to the spatial gradient (Werner et al., in prep), but its validity for inter-annual variations (Schmidt et al., 2007) and warmer than present-day conditions (Sime et al., 2009) is challenged.

In addition, under the exceptionally cold and dry conditions of the East Antarctic drilling sites, the contribution of postdeposition processes to the isotopic composition of the surface snow cannot be neglected (Town et al., 2008; Sokratov and 
The Cryosphere Discuss., doi:10.5194/tc-2016-263, 2016

Manuscript under review for journal The Cryosphere

Published: 17 November 2016

(c) Author(s) 2016. CC-BY 3.0 License.

Golubev, 2009). It has been recently evidenced that summer exchanges between snow and water vapour at the surface significantly affect the isotopic composition of the snow both in Greenland (Steen-Larsen et al., 2014) and on the East Antarctic Plateau (Ritter et al., 2016). In the first top metres of the snowpack, isotope exchanges involved during the snow metamorphism and the diffusion within the porous matrix additionally affect the isotopic composition of the snow (Langway, 1970; Johnsen, 1977; Whillans and Grootes, 1985). The diffusion length associated with these processes depends on the firn ventilation, the snow density and the exchange rate between the atmospheric water vapour and the surface snow (Waddington et al., 2002; Schneebeli and Sokratov, 2004; Sokratov and Golubev, 2009). This wide range of processes hampers the interpretation of the isotopic signal, in particular it is not clear how much of the original signal acquired during the formation of the precipitation is conserved during the burial of the snow.

10

Due to the extreme conditions on the East Antarctic Plateau, the general understanding of the processes involved in the hydrological cycle (out of any isotopic consideration) is not straightforward, and there remains open questions such as the definition of the accumulation, the estimation of the mass balance or the impact of snow metamorphism on the albedo feedback loop. In the case of accumulation, the low amount of precipitation (Petit et al., 1982; Frezzotti et al., 2007; Genthon et al., 2015) and the important contribution of blowing snow in the total deposition (Groot Zwaaftink et al., 2013; Picard et al., 2016a) creates patchiness in the accumulation, resulting in large uncertainties in the determination of the real precipitation amounts. Snow metamorphism is difficult to quantify due to the large noise created by the spatial variability, requiring a large number of samples every day. Using passive microwave satellite data, Picard et al. (2012) argue that the grain index is an indicator of the coarsening of snow grains and show its increase in summer to be anti-correlated with the integrated summer precipitation amount. Supersaturation is estimated from the combined measurements of humidity and temperature, both of which are complexified by the extreme conditions in Antarctica (Genthon et al., 2016). Including water isotopic composition as a tracer of the interactions between the snow pack and the atmospheric boundary layer could help refine our knowledge of the processes involved in the hydrological cycle in these regions.

Recent studies have focused either on the monitoring of the isotopic composition of the snow pack on the East Antarctic Plateau (Touzeau et al., 2016), of the precipitation (Fujita and Abe, 2006; Landais et al., 2012; Stenni et al., 2016), or of the atmospheric water vapour (Casado et al., 2016b; Ritter et al., 2016); exploring their links to climatic parameters and the implications for post-deposition processes during the archival of the climatic signal by the snow isotopic composition. Here, we study the isotopic composition of the continuum between atmospheric vapour, precipitation, surface and buried snow. To do so, we combine different datasets from the East Antarctic Plateau, based on published studies and new results, in order to qualitatively characterise the different processes affecting surface snow isotope composition at different time scales. We first report and compare the different methodologies applied for sampling surface snow, snow pits, precipitation and water vapour in the atmosphere (Section 2). Then, we present the results from these different studies including surface snow measurements over several years, precipitation measurements, vapour and snow measurements and snow pits sampling (Section 3). Finally, 
The Cryosphere Discuss., doi:10.5194/tc-2016-263, 2016

Manuscript under review for journal The Cryosphere

Published: 17 November 2016

(c) Author(s) 2016. CC-BY 3.0 License.

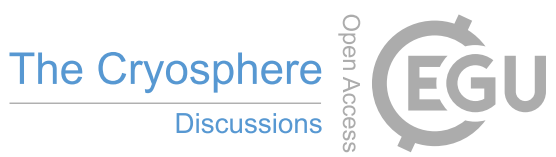

(c) (i)

we discuss the impact of post-deposition processes at the snow surface through the exchanges between the snow and the vapour and within the firn (Section 4) before summarising our key conclusions.

\section{Sites, material and methods}

\subsection{Sites}

5 The East Antarctic Plateau is a high elevation area, over 2500 metres above sea level (ma.s.l.) covered with snow and ice spreading on most of the eastern continental part of Antarctica (Fig. 1). The East Antarctic Plateau is characterised by mean annual temperatures below $-30^{\circ} \mathrm{C}$ and accumulation below $80 \mathrm{~kg} \cdot \mathrm{m}^{-2} \cdot \mathrm{yr}^{-1}$, as illustrated in Fig. 1 .

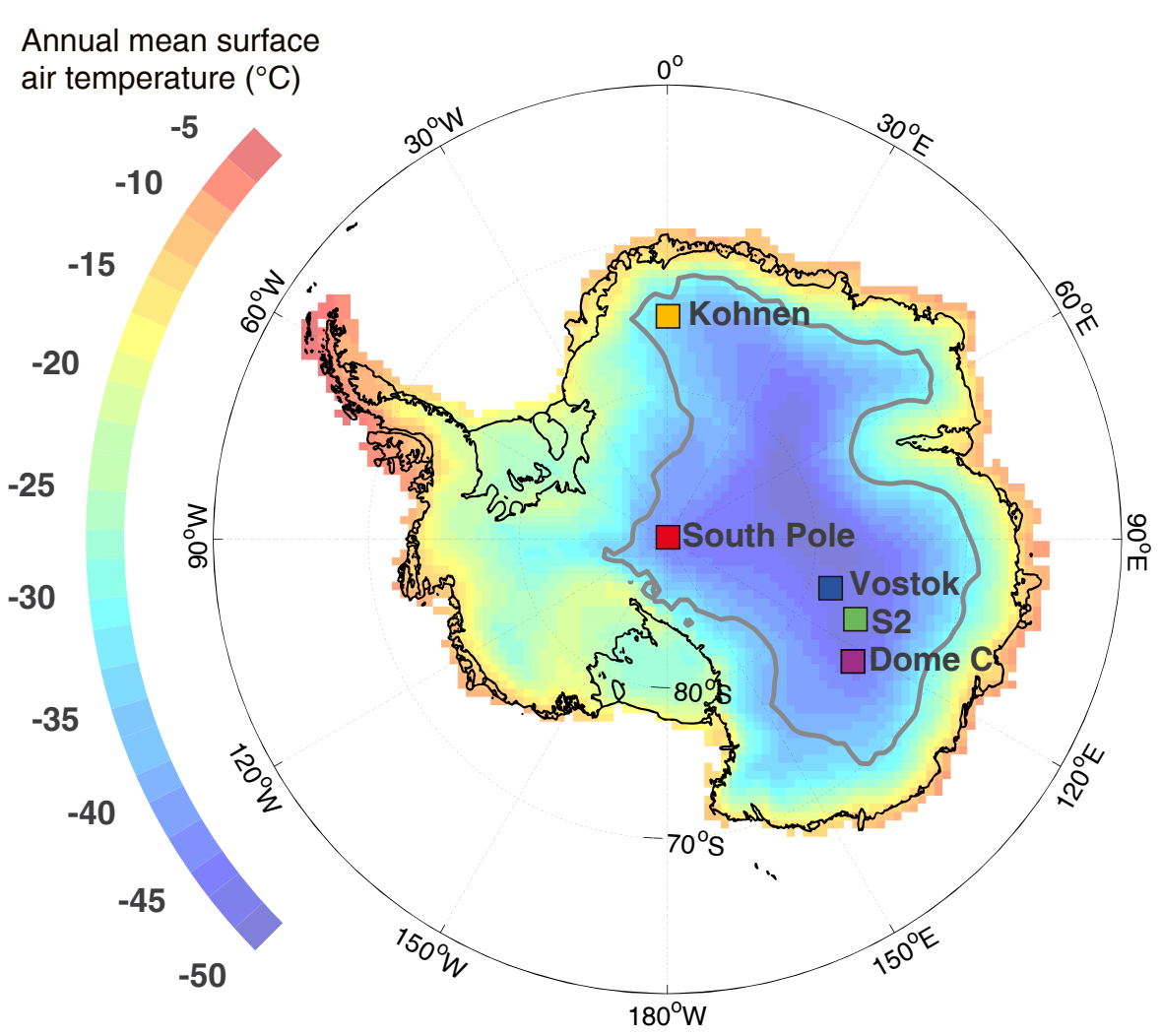

Samples available
Kohnen
2 snowpits
Summer 2014/15
Vapour monitoring
Summer 2013/14
Vostok
7 snowpits
from 1999 to 2012
Precipitation samples
in 2000
S2
1 snowpit
Summer $2012 / 13$
Dome C
5 snowpits
from 1977 to 2015
Precipitation samples
from 2008 to 2011
Surface snow
from 2011 to 2015
Vapour monitoring
Summer $2014 / 15$
South Pole
1 snow pit in 1978
1 snow pit in 1989

Figure 1. Map of Antarctica highlighting the East Antarctic Plateau (grey line = contour of $2500 \mathrm{~m}$ a.s.l. elevation) indicating the location of the sampling sites (solid squares) included in this work. Colours indicate the annual mean surface air temperature at $2 \mathrm{~m}$ modified from the ERA-interim dataset from 1979 to 2009 (Nicolas and Bromwich, 2014). 
The Cryosphere Discuss., doi:10.5194/tc-2016-263, 2016

Manuscript under review for journal The Cryosphere

Published: 17 November 2016

(c) Author(s) 2016. CC-BY 3.0 License.

This study mainly focuses on Dome C, the site of the Concordia overwintering station, enabling year-long operations and thus giving the rare opportunity to study the entire seasonal cycle of isotopic composition. We extend the results to the entire East Antarctic Plateau by comparing the data from Dome C to observations from the Kohnen, Vostok and Amundsen-Scott South-Pole stations and from the point S2 which is one of the drilling sites of the campaign Explore-Vanish joining Dome C and Vostok (see Fig. 1). These locations span a large range of climatic conditions of the East Antarctic Plateau as illustrated on Table 1.

Table 1. Climatic conditions at the different sites used in this study (Alley, 1980; Petit et al., 1982; Wendler and Kodama, 1984; Oerter et al., 2000; Ekaykin et al., 2002; van As et al., 2007; Lazzara et al., 2012; Casey et al., 2014; Genthon et al., 2015; Touzeau et al., 2016; Laepple et al., 2016)

\begin{tabular}{lcccccc}
\hline Site & Location & $\begin{array}{c}\text { Altitude } \\
(m \text { a.s.l. })\end{array}$ & $\begin{array}{c}\text { AWS mean } \\
\text { temperature }\left({ }^{\circ} \mathrm{C}\right)\end{array}$ & $\begin{array}{c}10 m \text { firn } \\
\text { temperature }\left({ }^{\circ} \mathrm{C}\right)\end{array}$ & $\begin{array}{c}\text { Accumulation } \\
\left(k g . m^{-2} . y r^{-1}\right)\end{array}$ & $\begin{array}{c}\text { Mean wind } \\
\text { speed }\left({\mathrm{m} . s^{-1}}^{-1}\right)\end{array}$ \\
\hline Kohnen & $75.0^{\circ} \mathrm{S}-0.1^{\circ} \mathrm{E}$ & 2892 & -42.2 & -44.5 & $62-73$ & 4.5 \\
Vostok & $78.5^{\circ} \mathrm{S}-106.8^{\circ} \mathrm{E}$ & 3488 & -55.2 & -57 & 21 & 5.1 \\
$\mathrm{~S} 2$ & $76.3^{\circ} \mathrm{S}-120^{\circ} \mathrm{E}$ & 3229 & $\mathrm{NA}$ & -55.1 & 21 & $\mathrm{NA}$ \\
Dome $\mathrm{C}$ & $75.1^{\circ} \mathrm{S}-123.3^{\circ} \mathrm{E}$ & 3233 & -52.4 & -54.3 & 27 & 3.3 \\
South Pole & $90^{\circ} \mathrm{S}-0^{\circ} \mathrm{E}$ & 2835 & -49.3 & -50.8 & 80 & 4.1 \\
\hline
\end{tabular}

\subsection{Surface snow and precipitation sampling}

Precipitation and surface snow have been sampled at Dome C regularly by different teams since 2008. Here, we report new measurements of precipitation and surface snow together with previously published data from Stenni et al. (2016) and Touzeau et al. (2016) (see Table 2). Because different teams were in charge of the different sampling activities, the protocols differ between the years.

The sampling protocol of the 2011 campaign (SUNITEDC) has been precisely described by Touzeau et al. (2016): the upper first millimetres of snow (1 to $5 \mathrm{~mm}$ ) were gathered every 1-2 weeks using a metallic blade over a surface of 20 per $20 \mathrm{~cm}$. This leads to samples of approximately $20 \mathrm{~mL}$. The sampling areas were randomly picked provided the surface was flat.

During the NIVO project (from 2013 to 2015), the surface snow was gathered by sampling roughly $15 \mathrm{~mm}$ of snow with a corning flask over a surface of 20 per $10 \mathrm{~cm}$. This led to samples of approximately $50 \mathrm{~mL}$. The sampling areas of 2013/14 were chosen randomly in a 100 per $100 \mathrm{~m}$ "clean area" near the Atmospheric Shelter in parallel with density and specific surface area (SSA) measurements (see section 2.4). Two samples were collected during each collect and we present here the average value of the two samples. In addition, during summer 2013/14, regular samplings of surface and sub-surface snow were performed for almost 2 months. The surface samples were gathered using a corning flask from 0 to $3 \mathrm{~cm}$ depth. The sub-surface samples were gathered by the same tool from 3 to $6 \mathrm{~cm}$ depth. In 2014/15, an additional sampling took place within the GLACIO project 
The Cryosphere Discuss., doi:10.5194/tc-2016-263, 2016

Manuscript under review for journal The Cryosphere

Published: 17 November 2016

(c) Author(s) 2016. CC-BY 3.0 License.

twice a day from December 2014 to January 2015 near the location of the inlet used for water vapour monitoring (See section 2.4 and Casado et al. (2016b)) following the same protocol.

Sampling of surface snow and precipitation isotopic composition were carried out in parallel by the Italian winterover crews (program PRE-REC). Precipitation samples have been collected all year round on a 80 per $120 \mathrm{~cm}$ wooden table standing $1 \mathrm{~m}$ above the ground level $800 \mathrm{~m}$ from Concordia Station from 2008 to 2011. The samples were collected at 1 a.m. every day if the amount was sufficient. The surface snow samples were gathered from an adjacent wooden plate of 80 per $120 \mathrm{~cm}$ at ground level. If the amount of snow on this second table was sufficient, snow samples were collected. Both precipitation and surface snow samples were sealed into date-labelled plastic bags and preserved in frozen state until delivery and measurement in Italy. For the precipitation samples, the protocol is detailed by Stenni et al. (2016). It is important to note that the protocol of surface snow sampling from the PRE-REC campaign differ greatly from the protocols from the NIVO and SUNITEDC programs due to the presence of the wood plate.

Table 2. Summary of the different campaigns of surface snow and precipitation samplings presented here.

\begin{tabular}{lcccc}
\hline Project & Location & Years & $\begin{array}{c}\text { Resolution } \\
\text { (days) }\end{array}$ & Reference \\
\hline SUNITEDC (French) & Surface snow & 2011 & 7 & (Touzeau et al., 2016) \\
\hline PRE-REC (Italian) & Precipitation & 2008 to 2011 & 1 & Partially in (Stenni et al., 2016) \\
& Surface snow & 2012 and 2014 & 7 & This study \\
\hline NIVO (French) & Surface snow & 2013 to 2016 & 3 & This study \\
\hline GLACIO (French) & Sub-surface & $11 / 2013$ to 01/2014 & 1 & This study \\
\hline
\end{tabular}

\subsection{Snow pits sampling}

We present profiles of isotopic composition sampled in snow pits at Dome C : two unpublished profiles from the first preliminary campaigns at Dome C in 1978 and two new snow pit profiles obtained in 2014/15, dug $50 \mathrm{~m}$ apart in parallel with surface snow sampling and vapour monitoring. For one of them, snow temperature and density profiles were established. The samples were taken in plastic flasks and analysed later on in the laboratory. To extend the results to other sites of the East Antarctic Plateau, we additionally present snow pit samplings performed through several campaigns over different sites of East Antarctica which were realised and analysed by different teams. 
The Cryosphere Discuss., doi:10.5194/tc-2016-263, 2016

Manuscript under review for journal The Cryosphere

Published: 17 November 2016

(c) Author(s) 2016. CC-BY 3.0 License.

Table 3. Summary of the different snow pits presented in this study.

\begin{tabular}{lcccc}
\hline Station & Years & $\begin{array}{c}\text { Resolution } \\
(\mathrm{cm})\end{array}$ & $\begin{array}{c}\text { Number } \\
\text { of pits }\end{array}$ & Reference \\
\hline \multirow{2}{*}{ Vostok } & 2001 to 2015 & 2 to 5 & 6 & $\begin{array}{c}\text { Ekaykin et al. (2002, 2004, 2009) } \\
\text { Touzeau et al. (2016) }\end{array}$ \\
\hline Kohnen & $2012 / 13$ & 3 & 1 & This study \\
\hline \multirow{2}{*}{ Dome C } & $2014 / 15$ & 3 & 2 & This study \\
& $1977 / 78$ & 1 to 3 & 2 & Touzeau et al. (2016) \\
& $2012 / 13$ & 3 & 1 & This study \\
\hline S2 & $2014 / 15$ & 1.5 to 5 & 2 & Touzeau et al. (2016) \\
\hline \multirow{2}{*}{ South Pole } & $2012 / 13$ & 3 & 1 & Jouzel et al. (1983) \\
& 19878 & 2 & 1 & Whitlow et al. (1992) \\
\hline
\end{tabular}

Two new isotopic composition profiles from Kohnen are extracted from trenches, following the methodology reported in Münch et al. (2016) but down to $3.6 \mathrm{~m}$ depth sampled at a $3 \mathrm{~cm}$ vertical resolution. The two profiles are separated by approximately $500 \mathrm{~m}$. A large number of snow pits from Vostok station are presented here, they have been previously described in Ekaykin et al. $(2002,2004)$ and Ekaykin and Lipenkov (2009). We combine the results from six snow pits with depths varying from $2.5 \mathrm{~m}$ to $12 \mathrm{~m}$ and a minimum resolution of $5 \mathrm{~cm}$. In addition, snow pits from the Explore-Vanish campaign are included comprising one $3.5 \mathrm{~m}$ deep snow pit from Vostok, one $2.6 \mathrm{~m}$ deep from $\mathrm{S} 2$ and one $2 \mathrm{~m}$ deep from Dome $\mathrm{C}$, all of them including triple isotopic compositions $\left(\delta^{18} O, \delta^{17} O\right.$ and $\delta D$ ) published in Touzeau et al. (2016). Finally, we include two snow pits from South Pole (Jouzel et al., 1983; Whitlow et al., 1992).

\subsection{Atmospheric and snow surface monitoring}

Water vapour isotopic composition has been measured at Kohnen station in 2013/14 (Ritter et al., 2016) and at Dome C in 2014/15 (Casado et al., 2016b). In both cases, to reduce the noise, the dataset were averaged to hourly resolution and cover approximately one month. In parallel to water vapour isotopic composition monitoring, surface snow was sampled once to twice a day. For a period from 27 hours to 72 hours, the surface snow was sampled every hour to evaluate the diurnal cycle of both the vapour and the snow isotopic composition (see section 2.2).

Dome $\mathrm{C}$ hosts a large set of instruments probing the troposphere and the firn justifying to focus this study on this site. Here, we make use of temperature, wind speed and humidity measurements from the $45 \mathrm{~m}$ meteorological profiling system described by Genthon et al. (2013). The temperature and humidity observations are performed using ventilated thermohygrometers HMP155 and are therefore free of radiation biases (Genthon et al., 2011). The temperature reanalysis product (ERA interim) has been compared to ventilated automatic weather station data (AWS) from Genthon et al. (2013) and we found 
The Cryosphere Discuss., doi:10.5194/tc-2016-263, 2016

Manuscript under review for journal The Cryosphere

Published: 17 November 2016

(c) Author(s) 2016. CC-BY 3.0 License.

a good agreement at the seasonal scale and fairly good agreement at the event scale (not shown here). Depending on data availability (as the ventilated AWS were installed at Dome C in 2009), we will use either ERA-interim or measurements from AWS. An intercomparison when the two datasets are overlapping reveals that most of the variability from the day-to-day to the seasonal and inter-annual scales in captured by ERA-interim and major differences appear only for the evaluation of the diurnal cycle (not shown). Wind speed and direction are measured using Young 05103 and 05106 aerovanes. Snow surface temperature is measured with a Campbell scientific IR120 infrared probe located $2 m$ above ground level.

Finally, we include grain index observations (Picard et al., 2012) obtained by satellite measurements. The grain index is used as an indicator of the evolution of the size of the snow grains, and provides a qualitative evaluation of metamorphism. When available, we include Surface Sensitive Area (SSA) measurements also as an indicator of metamorphism (Libois et al., 2015). These optical methods are completed with snow surface observations. Frost deposition was monitored with a time lapse of the growth of hoar at the surface (see the video at https://vimeo.com/170463778). An image processing script was used to characterise the growth of a few crystals at the surface of the sastruga.

\subsection{Modelling approaches}

To highlight the impact of post-deposition processes, it is necessary to present how the surface snow isotopic composition differs from the initial precipitation signal formed during the Rayleigh distillation. Here, we make use of the Rayleigh-type Mixed Cloud Isotope Model (MCIM) developed by Ciais and Jouzel (1994) which computes the Rayleigh distillation along the air masses trajectories. The model includes microphysical properties of clouds and in particular takes into account mixed phase conditions. It is tuned with triple snow isotopic composition measured along a transect from Terra Nova Bay to Dome $\mathrm{C}$ (Landais et al., 2008). This tuning has been proven suitable to evaluate the variations of isotopic composition at Dome C (Winkler, 2012). This will provide a comparison between the spatial and the temporal slope of precipitation isotopic composition at the seasonal scale.

\section{Results}

In this section, we review the results from the different datasets, illustrating the different steps of the archival of climatic signal by the snow isotopic composition, from the precipitation to the buried snow (see Fig. 2).

We first present precipitation isotopic composition variations based on data from Stenni et al. (2016) and additional new data. We then present our new data of surface snow isotopic composition compared to the variations in $2 \mathrm{~m}$ surface air temperature, the grain size index and the precipitation isotopic composition, in order to evaluate at the day-to-day and at the seasonal scales the difference between surface snow and precipitation isotopic signals. We then report short time scale parallel measurements of vapour and surface snow isotopic composition, providing inputs on one of the major component of summer metamorphism on surface snow isotopic composition: the diurnal cycles of sublimation/condensation. We finally compare the isotopic com- 
The Cryosphere Discuss., doi:10.5194/tc-2016-263, 2016

Manuscript under review for journal The Cryosphere

Published: 17 November 2016

(c) Author(s) 2016. CC-BY 3.0 License.
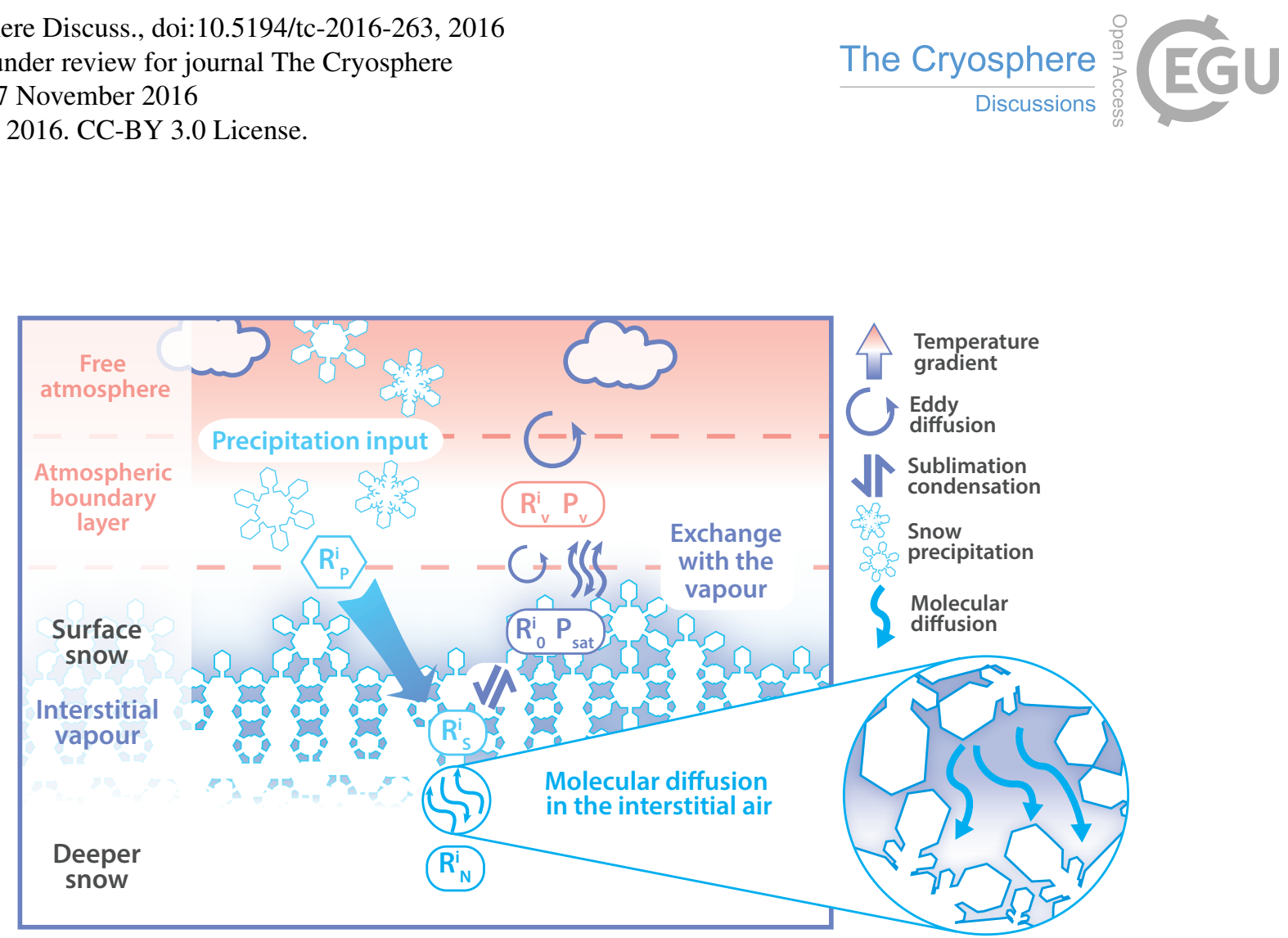

Figure 2. Schematic of the different contributions to the snow isotopic composition $\left(R_{X}^{i}\right.$ stands for the composition of isotope $i$ in the phase $X$ ) in remote Polar Regions: above the surface, both the precipitation and the sublimation/condensation cycles can contribute to the surface composition; in the open-porous firn below the surface, the snow can exchange with the air below the surface, enhanced or not by wind pumping. Deeper in the firn, molecular diffusion in the interstitial air affects the snow isotopic composition.

position of the surface, sub-surface and buried snow to evaluate the processes involved during the archival of the isotopic composition signal.

\subsection{Precipitation isotopic composition}

In this section, we present precipitation isotopic composition data at Dome C from Stenni et al. (2016) depicting 3 complete annual cycles from 2008 to 2010, completed by new, unpublished data from 2011 (Fig. 3).

At Dome $\mathrm{C}$, the precipitation isotopic composition presents a large variability at the day-to-day scale and a regular seasonal cycle. At the seasonal scale, precipitation isotopic composition is relatively well correlated to local temperature with a slope of $0.46 \%{ }^{\circ} \mathrm{C}^{-1}$, this slope is similar to the one obtained by Stenni et al. (2016) for the years 2008 to 2010 of $0.49 \pm 0.02 \% 0^{\circ} \mathrm{C}^{-1}$ $\left(R^{2}=0.63, n=500\right)$. No apparent lag between temperature and isotopic composition variations is observed.

Compared to other year-long precipitation sampling on the East Antarctic Plateau, this slope is lower than at Dome F (0.78 $\%{ }^{\circ} \mathrm{C}$ with $R^{2}=0.78$ (Fujita and Abe, 2006)) and higher than at Vostok $\left(0.26 \%{ }^{\circ} \mathrm{C}\right.$ with $R^{2}=0.58$ (Touzeau et al., 2016)). In summer, we systematically observe precipitation $\delta^{18} O$ above $-40 \%$ at Dome $\mathrm{C}$, whereas in winter, $\delta^{18} O$ values below -65 $\%$ are systematically observed. 
The Cryosphere Discuss., doi:10.5194/tc-2016-263, 2016

Manuscript under review for journal The Cryosphere

Published: 17 November 2016

(c) Author(s) 2016. CC-BY 3.0 License.

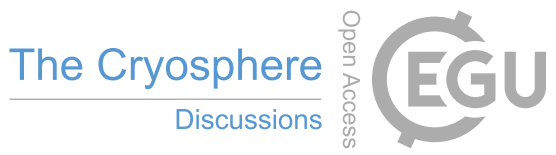

(c) (i)

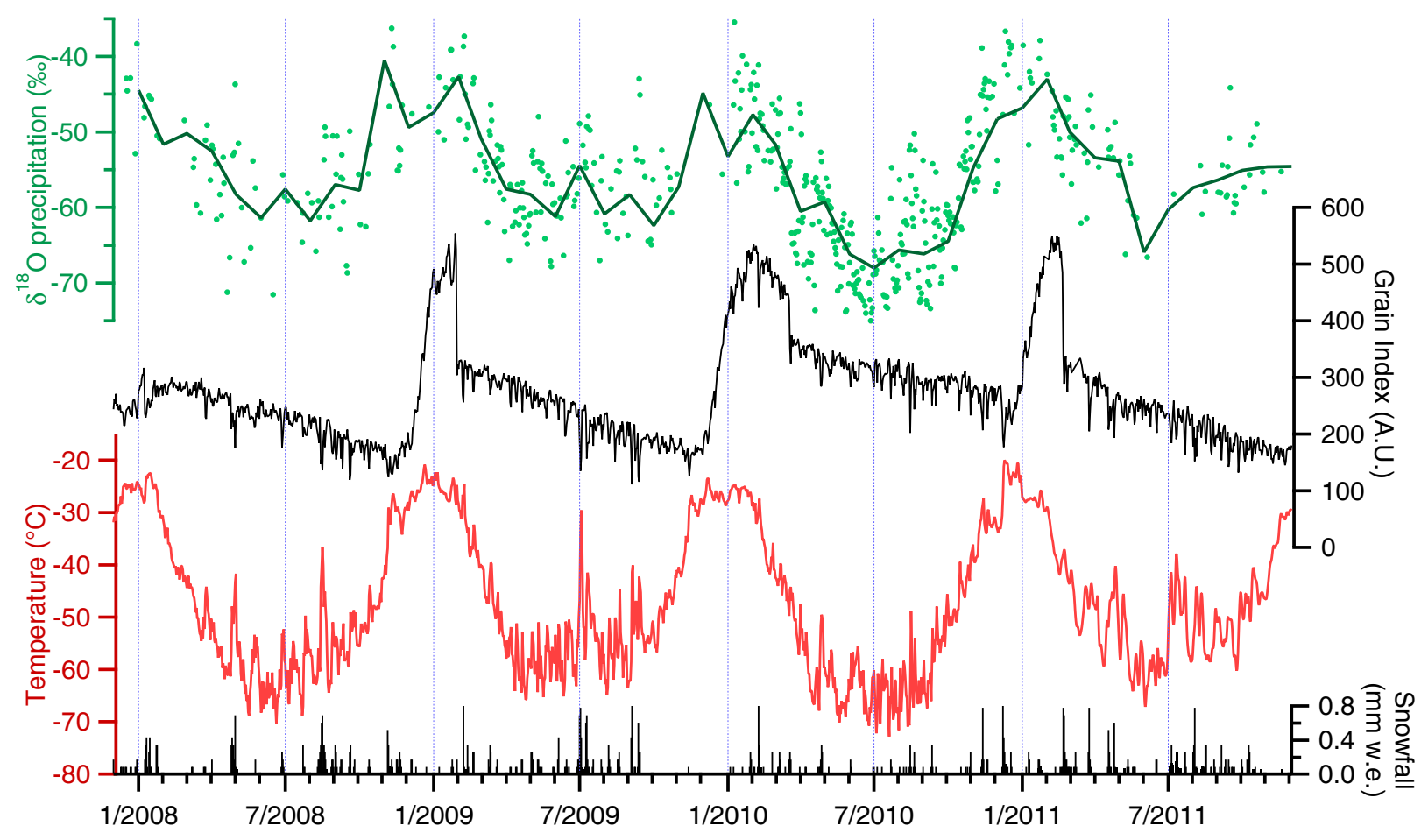

Figure 3. Four years (2008 to 2011) of monitoring at Dome $\mathrm{C}$ of the variations of precipitation isotopic composition from the PRE-REC campaign (Stenni et al., 2016) $\left(\delta^{18} O\right.$, green, dots: raw data, line: monthly average) in surface air temperature from the reanalysis ERA-interim (red line), grain index from satellite observations (black line) and snowfall amount calculated from the reanalysis ERA-interim (black bars).

\subsection{Surface snow isotopic composition}

Here, we present measurements of surface snow isotopic composition at Dome C from December 2010 to January 2016 (Fig. 4) combining results from Touzeau et al. (2016) with new data presented for the first time in this study from the PRE-REC, NIVO and GLACIO projects. The dataset includes three complete annual cycles of surface snow isotopic composition (in 2011, 2014 and 2015) and part of the 2012 cycle, with the respective temperature variations from AWS (Genthon et al., 2013) and the precipitation events (from reanalysis products). Note here that we use the available data from AWS in this section and not reanalysis products as in section 3.1 (see section 2.4).

First, we focus on the spatial variability impact on the measurements. To disentangle the local (below $1 \mathrm{~km}$ ) spatial variability from the temporal variations of the surface snow isotopic composition (Fig. 4), we compare the duplicate measurements realised during the year 2014 (Fig. 5). Indeed, for this year, several sets of measurements are available: one sampled at a fixed location on a wood surface (PRE-REC, blue dots) and one sampled randomly from the snow surface in a large field (NIVO, 
The Cryosphere Discuss., doi:10.5194/tc-2016-263, 2016

Manuscript under review for journal The Cryosphere

Published: 17 November 2016

(c) Author(s) 2016. CC-BY 3.0 License.

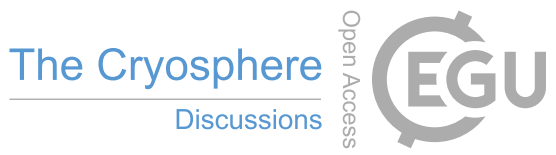

\section{(c) (1)}

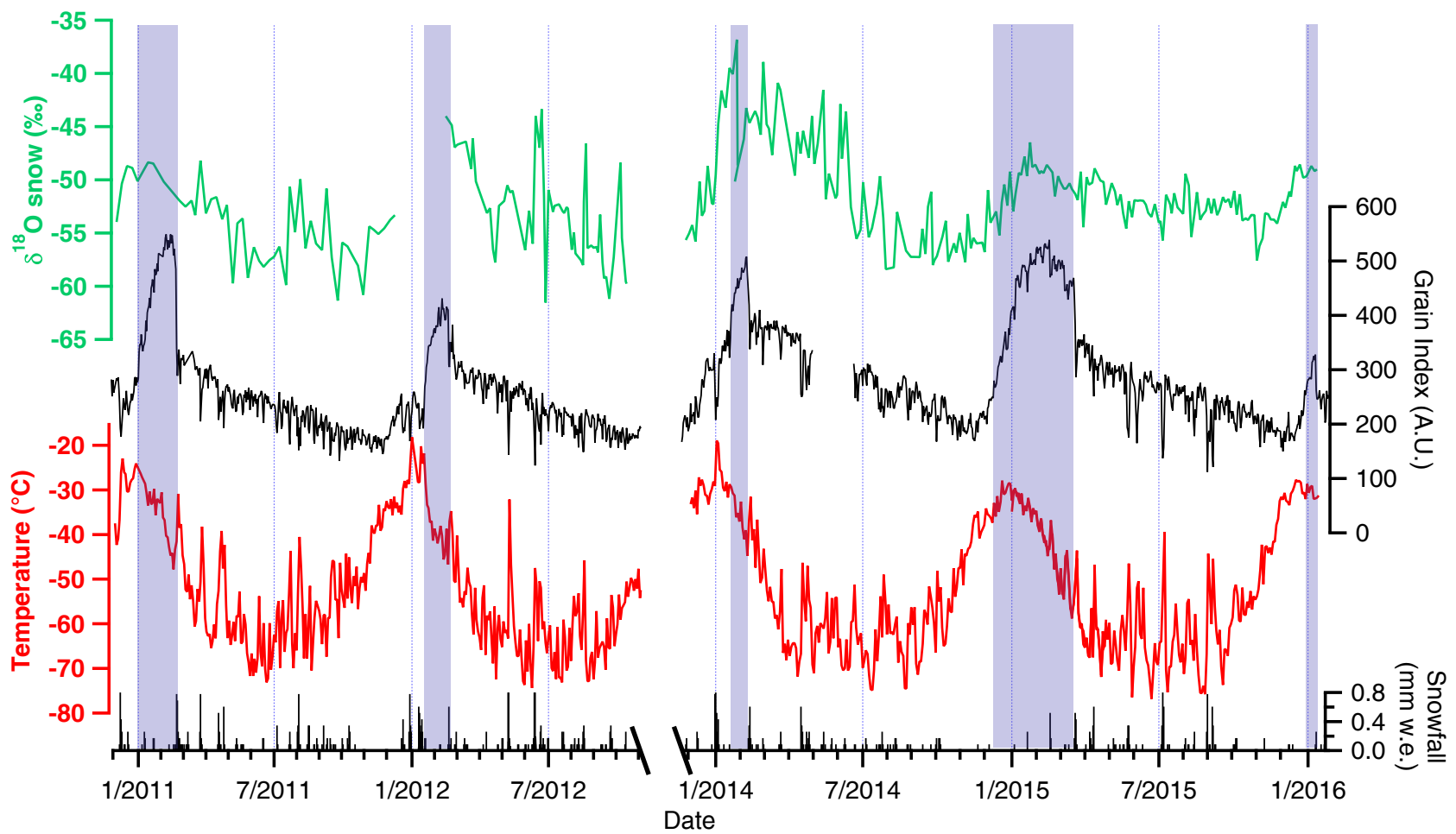

Figure 4. Surface snow isotopic composition $\left(\delta^{18} O\right.$, green lines) sampling from December 2010 to 2015: Dec 2010 to Dec 2011, data from the project SUNITEDC (Touzeau et al., 2016); Feb 2012 to Oct 2012, data from the project PRE-REC (this study); Nov 2013 to Jan 2016 , data from the project NIVO (This study). For comparison: AWS $2 m$ temperature measurements (Genthon et al., 2013) (red line), grain index (Picard et al., 2012) (black fine line) and precipitation (black bars) from ERA-interim reanalysis product. The blue shaded areas highlight the high grain index values (arbitrary threshold).

red line) as described in section 2.2. For the NIVO datapoints, we additionally present the raw maximum and minimum values obtained from duplicates. Strong differences are visible at the event scale, in particular during some events in March May and June. During these events, the very low values of the PRE-REC sampling reflect the isotopic composition of precipitation (not shown, Dreossi et al., in prep). This indicates that the sampling directly on the surface snow is a mixture of newly accumulated and existing snow and thus shows smaller variations than the wood surface and the precipitation itself. Also, when comparing the PRE-REC results to the NIVO results, there is an average difference of $4 \%$, which we attribute here to spatial variability. At the event scale (synoptic event of typically a couple of days), the variations of the surface snow isotopic composition exhibit an important small scale spatial variability (meter scale) due to the patchiness of the accumulation and of the frost deposition. Caution in interpretation of variations of surface snow isotopic composition at short time scale is therefore necessary. Larger statistics would be necessary to distinguish the climatic signal from the sampling variability. Still, the overall trends of the different datasets (and therefore representing different locations) are similar and demonstrate that the temporal variations are larger than the spatial variations. We estimate the spatial uncertainty of the surface snow isotopic composition measurements 
The Cryosphere Discuss., doi:10.5194/tc-2016-263, 2016

Manuscript under review for journal The Cryosphere

Published: 17 November 2016

(c) Author(s) 2016. CC-BY 3.0 License.

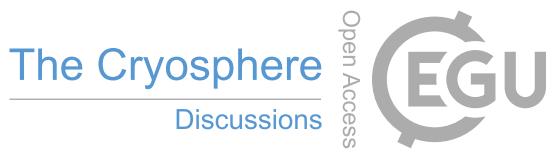

(c) (i)

to be $1.7 \%$ for $\delta^{18} O$ from the standard deviation calculated with the duplicates on the NIVO samples (randomly picked within $50 \mathrm{~m})$.

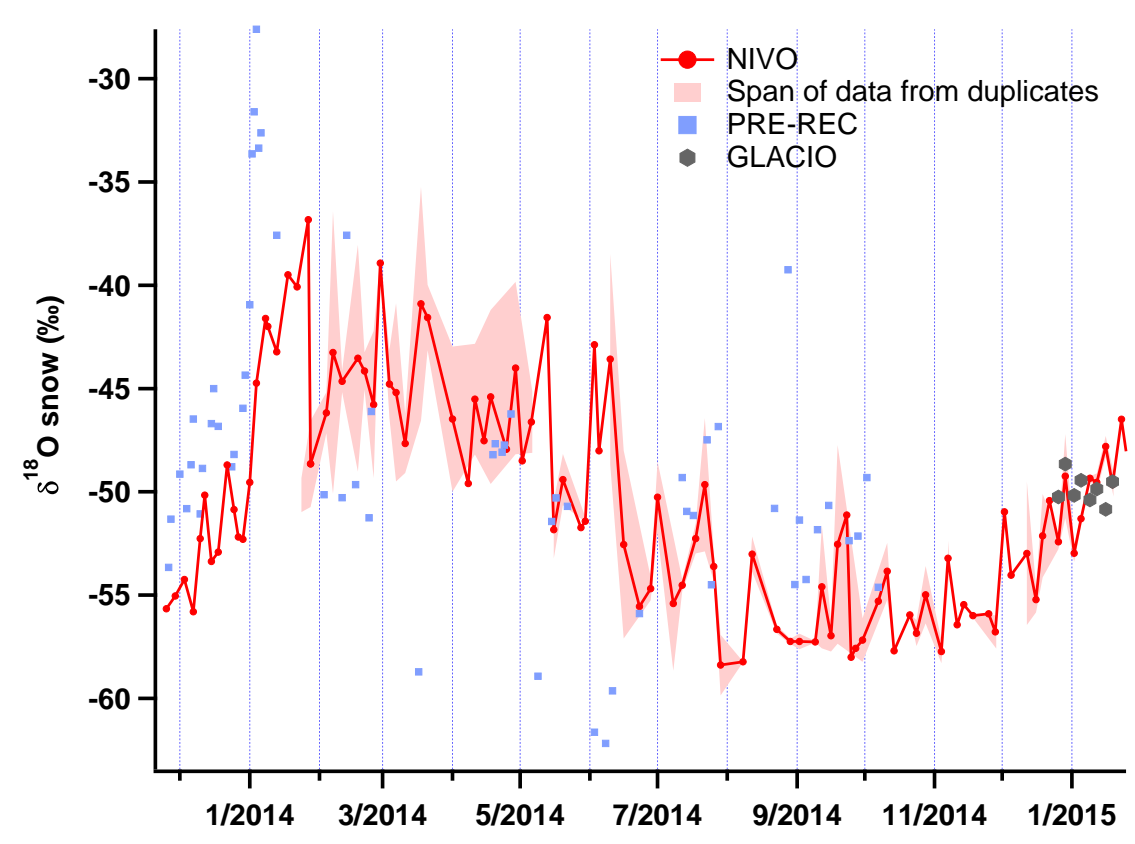

Figure 5. Reproducibility of surface snow isotopic composition measured in 2014. The NIVO dataset (red dots and line, duplicate span represented by the red shade, corresponding to the green line in Fig. 4) is compared to measurements obtained by independent teams (PREREC, blue dots; GLACIO, grey hexagon) and independent methods: PRE-REC snow samples were collected from a wood table whereas NIVO and GLACIO snow samples were collected directly from the surface snow.

Second, we focus on the temporal variability at different time scales. The three years (2011, 2014 and 2015) present the 5 typical temperature variations for the East Antarctic Plateau: a short, "warm" summer before a long, rather constant, winter as described by Van Den Broeke (1998). Over this cycle are imprinted short warm events often associated with advection of warmer air masses and precipitation events; these warms events are particularly visible in winter. We observe a similar pattern for $\delta^{18} O$ of the surface snow: annual cycles with a steep maximum centred on January (roughly a month after the temperature maximum) and a gradual decrease along most of the winter delayed by several months when compared to local temperature. Over these annual cycles, peaks of $\delta^{18} \mathrm{O}$ of surface snow occur and some of them might be related to warm precipitation events as previously suggested by Touzeau et al. (2016).

The winter values of the surface snow isotopic composition are similar between all observed years but the summer values show strong inter-annual variations, resulting in variable amplitudes of the annual cycles of $\delta^{18} O$. In 2011 and 2015, the ampli- 
The Cryosphere Discuss., doi:10.5194/tc-2016-263, 2016

Manuscript under review for journal The Cryosphere

Published: 17 November 2016

(c) Author(s) 2016. CC-BY 3.0 License.

tude of the annual cycle is below $10 \%$ in $\delta^{18} O$, whereas it is above $20 \%$ in 2014. In 2012, despite missing data at the beginning of the year, we observe variations of $\delta^{18} O$ more similar to the ones of 2014 than to the one of 2011 and 2015 with a difference of $15 \%$ in $\delta^{18} \mathrm{O}$ between the maximum at the beginning of February and the minimum in September. These differences are significant with respect to the results obtained from replicate samples.

Third, in Fig. 4, we present the grain index estimated from satellite data (Picard et al., 2012) to evaluate the impact of metamorphism on the surface snow. Periods of strong metamorphism identified during the summer are highlighted (blue shaded areas) using an arbitrary level on the summer grain index increase. We observe a link between summer grain index highs and the amplitude of the seasonal variation of $\delta^{18} O$ of the surface snow: in 2011 and 2015, small cycles of $\delta^{18} O$ are associated with a large grain index starting to increase in December; whereas in 2014 (and partially in 2012), the large summer increase of $\delta^{18} \mathrm{O}$ is associated with small summer increase of grain index, in this case delayed after mid-January. Such a pattern is not observed for precipitation (Fig. 3) whose isotopic composition seasonal variations appear more regular and in phase with temperature.

Finally, we focus on the slope between surface snow isotopic composition and temperature to evaluate if the slope between isotopic composition and temperature observed in precipitation is conserved in surface snow after being impacted by postdeposition processes. Because the timeseries of surface snow $\delta^{18} O$ and of temperature are not in phase, it is not possible to directly estimate the corresponding temporal slope by linear regression. This is particularly important in 2014 when the amplitude of the isotopic composition cycle is maximal. We therefore estimate the relationship by comparing the peak to peak range in temperatures and isotopic composition. As the phase lag is smaller in 2011, we use this year to compare the peakto-peak slope to the linear regression. For 2011, during which the amplitude of the isotopic composition seasonal cycle is greatly reduced with respect to 2014, the slope between $\delta^{18} O$ and temperature is $0.14 \% o^{\circ} \mathrm{C}^{-1}$ (Touzeau et al., 2016) rising up to $0.22 \% 0^{\circ} \mathrm{C}^{-1}$ if considering the difference between maximum summer values and minimum winter values. For 2014, we obtain a slope of $0.49 \% 0^{\circ} \mathrm{C}^{-1}$, lower than the prediction of the MCIM of almost $1 \% 0^{\circ} \mathrm{C}^{-1}$ but closer to the value of the slope between $\delta^{18} \mathrm{O}$ and temperature reported by Touzeau et al. (2016) of $0.46 \%{ }^{\circ} \mathrm{C}^{-1}$ in precipitation at Dome C (see Stenni et al. (2016) and Table 5).

This illustrates that, at the seasonal scale, the seasonal amplitude of variations in surface snow isotopic composition is greatly reduced compared to that of precipitation.

\subsection{Exchanges between atmospheric water vapour and snow isotopic composition}

In this section, we focus on the isotope exchanges between the surface snow and the atmospheric vapour at the diurnal to day-to-day scales by comparing measurements of vapour isotopic composition from Casado et al. (2016b) with new results of surface snow isotopic composition from samples obtained in parallel with the vapour monitoring. To evaluate the impact of sublimation/condensation cycles on the snow isotopic composition, we performed hourly samplings of the snow isotopic 
The Cryosphere Discuss., doi:10.5194/tc-2016-263, 2016

Manuscript under review for journal The Cryosphere

Published: 17 November 2016

(c) Author(s) 2016. CC-BY 3.0 License.

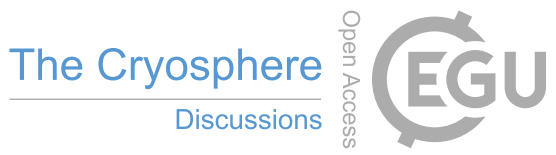

(c) (i)

composition during 24 hours at Dome $\mathrm{C}$ in parallel with vapour isotopic composition monitoring. In Fig. 6, we present the simultaneous evolution of snow and vapour isotopic compositions over 24 hours on the 7th of January 2015.

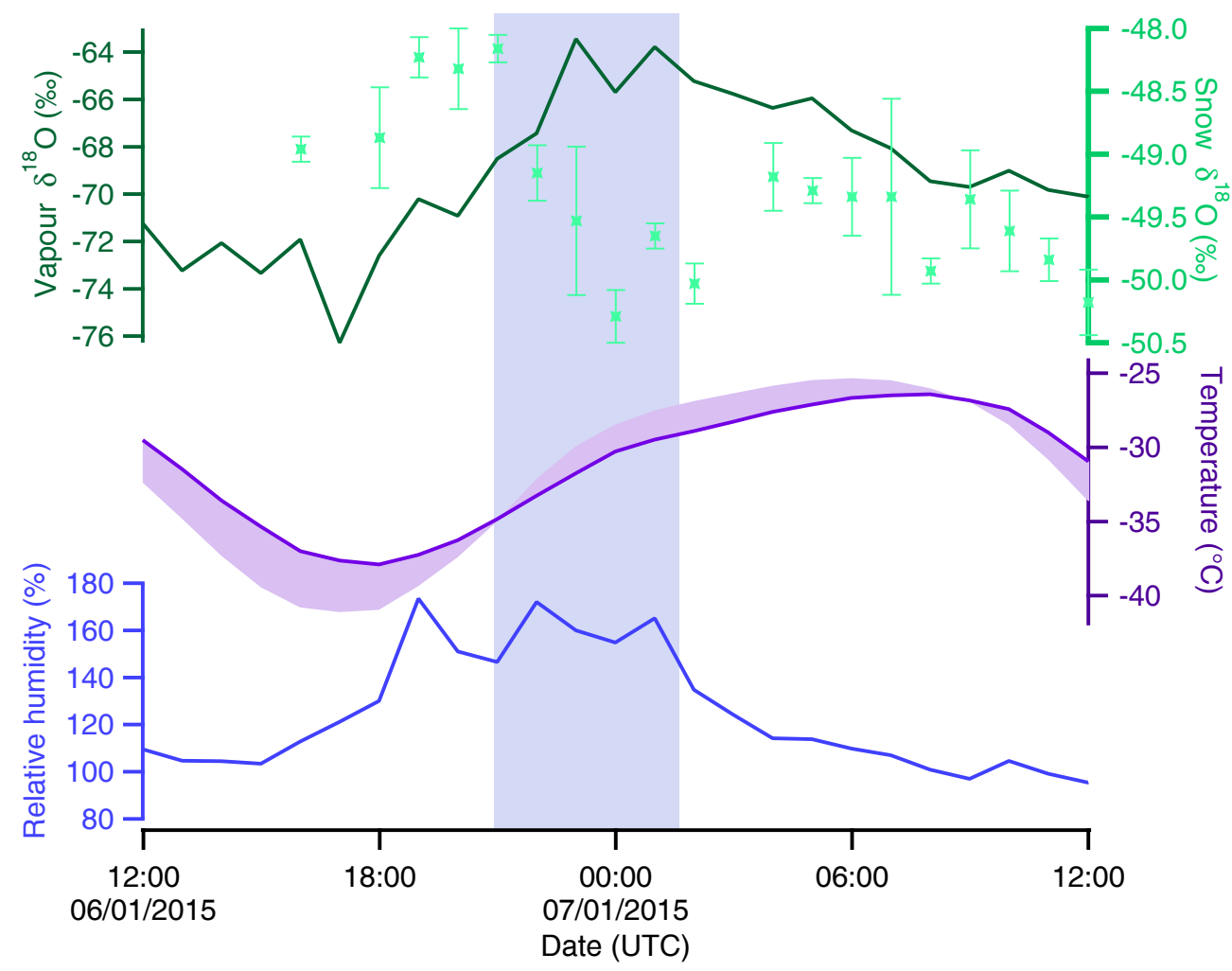

Figure 6. Isotopic composition of surface snow (light green dots, error bars are obtained from replicates) compared with isotopic composition of water vapour (dark green line) during one typical summer day at Dome C, with $3 \mathrm{~m}$-temperature (purple line) compared to the surface temperature (light purple shade) and to the relative humidity (blue line) during the same period from Casado et al. (2016b). The blue shaded area marks the time-period when frost deposition was observed (see the time-lapse video: https://vimeo.com/170463778)

To evaluate the impact exchanges between snow and vapour on surface snow isotopic composition, we chose the 7th of 5 January as a case study. Indeed, it was characterised by a large diurnal cycle in water vapour isotopic composition, humidity and temperature associated with a turbulent and convective atmospheric boundary layer enabling important exchanges of moisture between snow and vapour (Casado et al., 2016b). This is a common situation in summer at Dome $\mathrm{C}$ due to weak katabatic winds. The afternoon was perturbed by the advection of a frontal perturbation (not shown) which affected the value of the vapour isotopic composition from 06:00 on the 7th of January (the maximum of $\delta^{18} O$ is typically reached around 06:00 UTC). To study the exchanges between snow and vapour free of the impact of meteorological events, we therefore focus on the night from 18:00 on the 6th of January to 5:00 on the 7th of January. In addition to the isotopic composition of the vapour 
The Cryosphere Discuss., doi:10.5194/tc-2016-263, 2016

Manuscript under review for journal The Cryosphere

Published: 17 November 2016

(c) Author(s) 2016. CC-BY 3.0 License.

and of the surface snow are presented in Fig. 6 the 3m-temperature measured by AWS, the surface temperature measured by infrared sensing (Casado et al., 2016b) and the relative humidity calculated from the specific humidity measured by the Picarro laser instruments and the saturated vapour pressure at the ground temperature (Goff and Gratch, 1945). Note that due to intake of snow crystals in the inlet of the Picarro, relative humidity is overestimated in very supersaturated conditions, still other hygrometers installed at Dome C indicated supersaturated conditions with relative humidity ranging between 105\% and 125\% between 19:00 on the 6th of January and 06:00 on the 7th of January. Measurements of supersaturation are complicated by the loss of water vapour at the condensation on the surface of instruments for non-heated instruments and sampling of floating microcrystals for heated instruments (Genthon et al., 2016).

During this five hours period, water vapour $\delta^{18} O$ increased from $-73 \%$ o to $-64 \%$ The evolution of water vapour isotopic composition is synchronous to observations of mist and frost deposition due to local large supersaturation (see the time-lapse video: https://vimeo.com/170463778). This situation is typical for the "night" at Dome C in summer, and thus is an typical illustration of the "night" deposition of frost.

During this event of frost deposition, snow $\delta^{18} O$ decreased by roughly $2 \%$. From 21:30 on the 6th of January (UTC time) to 01:40 on the 7th of January (UTC time), the volumes of three snow crystals have been monitored by a script transferring the size in pixels of each crystals from the video on this link (https://vimeo.com/170463778) to surfaces using a length etalon and estimating the volume variations using a power law from the surface variations. This shows an increase by a factor from 1.5 to 3.9. The growth of the crystals observed in the time-lapse can be interpreted as the deposition of an amount of ice large enough to significantly affect the isotopic composition. The frost deposition occurs simultaneously with the modification of the isotopic composition of the snow and of the vapour. These observations can be explained by an exchange of molecules between the snow and the vapour affecting significantly the snow isotopic composition leading to an enrichment of the isotopic composition of the vapour and a depletion of the isotopic composition of the snow. While this new line of evidence clearly shows vapour-snow isotopic variations associated with frost deposition, it remains to be confirmed by an extended monitoring over several days.

\subsection{Surface and sub-surface snow isotopic exchanges}

In this section we investigate the difference in isotopic composition between surface and sub-surface ( $5 \mathrm{~cm}$ below the surface) snow. First, we want to test if the delay observed between the variations of surface snow isotopic composition and temperature is due to the sampling procedure (see section 3.2). Second, we want to investigate how is the isotopic signal propagated inside the firn, from the surface to the sub-surface.

During the summer 2013/14, regular samplings of surface ( 0 to $3 \mathrm{~cm}$ ) and sub-surface ( 3 to $6 \mathrm{~cm}$ ) snow have been realised at Dome C. Once a day, 2 samples of snow at each level have been taken along with specific surface area (SSA) measurements to evaluate the size of the grains and therefore, how much metamorphism has taken place (Picard et al., 2016b). These data are 
The Cryosphere Discuss., doi:10.5194/tc-2016-263, 2016

Manuscript under review for journal The Cryosphere

Published: 17 November 2016

(c) Author(s) 2016. CC-BY 3.0 License.

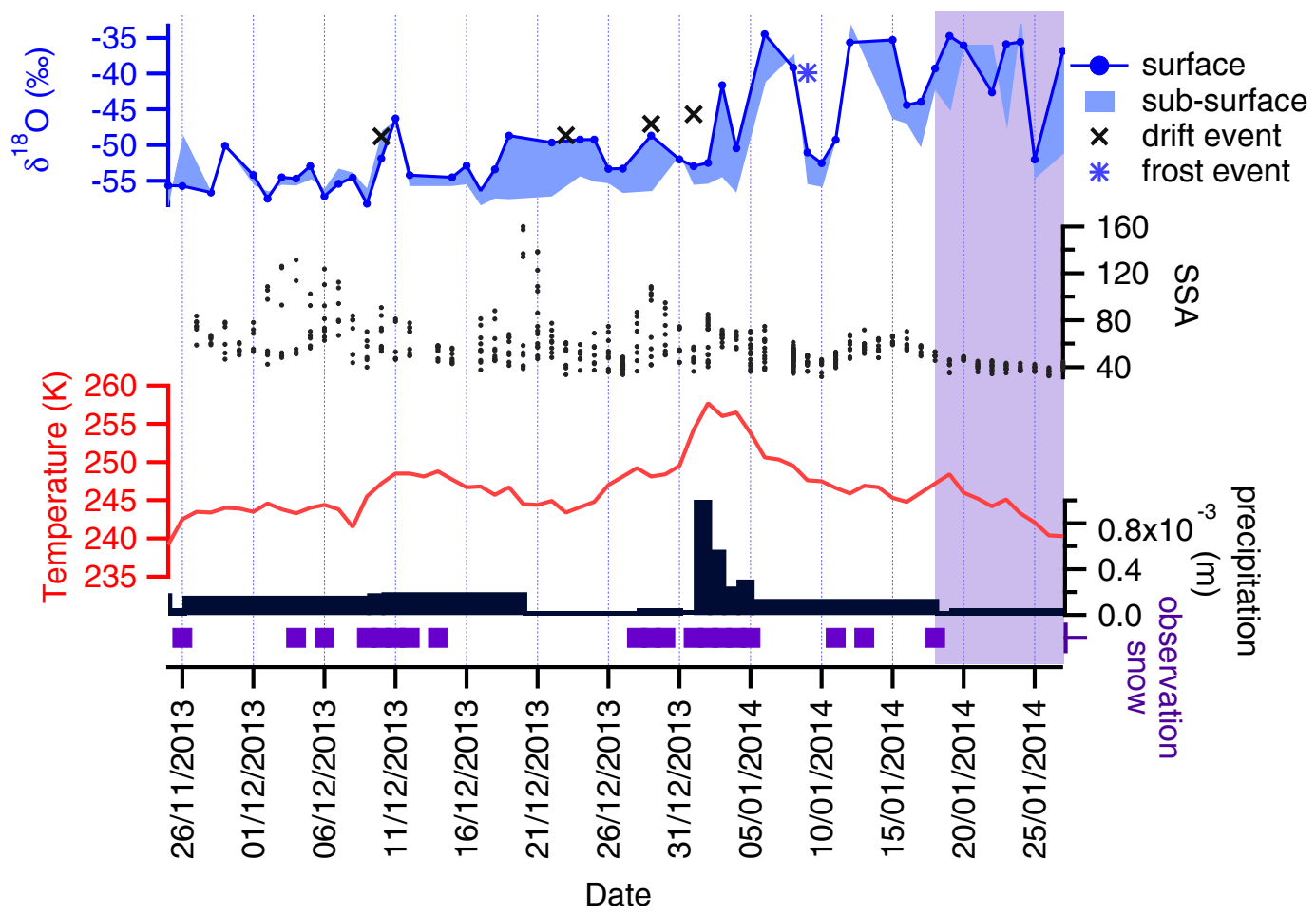

Figure 7. Isotopic composition of the snow at the surface (blue line) and difference between surface and the sub-surface (blue shade) during 2 months at Dome C in 2013/14, compared with SSA measurements (black dots), temperature (red line) and precipitation (black bars) from ERA-interim, and precipitation observations (purple squares). The shaded area corresponds to the period during which the grain index changes reflect large metamorphism (see section 3.2).

presented in Fig. 7 with the temperature and the precipitation from reanalysis products and in-situ observations of precipitation. We observe that overall, during these two summer months, the sub-surface isotopic composition is almost systematically lower than the surface isotopic composition. This is found as well in most of the snow pits presented in this manuscript (see section 3.5).

From the end of November to the 15th of December, we observe similar values of surface and sub-surface snow isotopic composition. This is a period during which metamorphism has not started yet as indicated by the large values of SSA (Fig. 7). The surface snow isotopic composition is low (around -55\%o) and the SSA is high which is typical of winter snow. From the 16th of December, we observe large differences between the surface and the sub-surface snow isotopic composition (up to 5\%o higher at the surface) and the SSA decreases indicating the metamorphism is effective. Until the 31st of December, numerous drift events mix the snow and therefore cause strong spatial variability. Finally, due to a large episode of precipitation around the 2 nd of January, we observe a significant increase of snow $\delta^{18} O$ of $18 \%$ at the surface first and at the sub-surface no more 
The Cryosphere Discuss., doi:10.5194/tc-2016-263, 2016

Manuscript under review for journal The Cryosphere

Published: 17 November 2016

(c) Author(s) 2016. CC-BY 3.0 License.

than two days later. The accumulation of snow associated with this event cannot account for enough snow to create a layer of $5 \mathrm{~cm}$ as the annual accumulation at Dome $\mathrm{C}$ is barely $8 \mathrm{~cm}$. If the surface snow isotopic composition seems to be directly affected by this precipitation event, it seems that the subsurface snow isotopic composition is less sensitive to this impact and that it only changes as a reaction of the surface changes.

As illustrated in Fig. 4, the grain index shows that strong metamorphism only starts in the middle of January (high grain index increase is indicating strong metamorphism, in the case of SSA, accumulation of metamorphism results in a small SSA). During this period, we observe a large variability of both the surface and the sub-surface snow isotopic composition. It is important to note here that the variations of isotopic composition include both spatial and temporal variations as only one sample per day was realised, therefore some of the variability might be spatial variability.

A single frost event, on the 9th of January, seems to have depleted strongly the snow in heavy isotopes, but any robust analysis would require more events to discriminate the impact of the frost event from the spatial variability.

\subsection{Signal in the snow pits}

At the annual or seasonal scale, there is no consensus whether or not snow isotopic composition archives the climatic conditions on the East Antarctic Plateau. Ekaykin et al. (2002) observed 20 to $30 \mathrm{~cm}$ cycles in the isotopic composition of the snow at Vostok. Here, we compare the oscillations of the snow isotopic composition of five sites on the East Antarctic Plateau (Dome C, Kohnen, S2, South Pole and Vostok) which are characterised by different meteorological and glaciological parameters such as mean annual temperature, elevation, wind speed and direction, accumulation or sastrugi height. A representative subsection of the profiles of isotopic composition from the different sites is presented in Fig. 8.

We analyse the typical varriations observed in the snow pits by manual counting of the successive local extrema with a threshold of minimum $1.5 \%$ or $\delta^{18} O$ and $10 \%$ for $\delta D$ for the difference between a minimum and a maximum (in both cases, the thresholds are chosen higher than the measurement precision and lower than the annual variations of surface snow isotopic composition; sensitivity tests have been realised that show insignificant impacts). For each snow pit, the mean cycle length is estimated by counting the number of maxima over the length of the pit. We present the average of the cycle length of the different pits for each site (Table 4).

Manual counting shows recurrent $20 \mathrm{~cm}$ 'cycles' across most of the Antarctic Plateau (Table 4). This signal is particularly robust for sites such as Vostok with seven snowpits with cycle lengths between 19 and $26 \mathrm{~cm}$ and for Kohnen with 2 snowpits with cycle lengths between 17 and $23 \mathrm{~cm}$. Similar cycle lengths are generally observed for $\delta D$ and $\delta^{18} O$, but our manual counting method applied on a limited number of pits with a relatively low resolution would not allow to detect small differences. Still, for one pit at $\mathrm{S} 2$ where we observe a difference of $4 \mathrm{~cm}$ between the length of the cycle in $\delta D$ and in $\delta^{18} O$. This difference is due to one skipped local maximum in the case of $\delta^{18} O$ compared to $\delta D$ and shows the limits of the counting of successive 
The Cryosphere Discuss., doi:10.5194/tc-2016-263, 2016

Manuscript under review for journal The Cryosphere

Published: 17 November 2016

(c) Author(s) 2016. CC-BY 3.0 License.

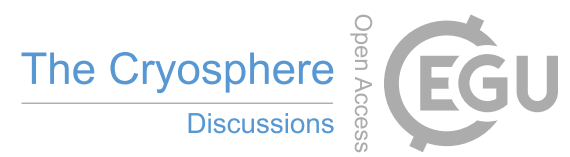

(c) (i)

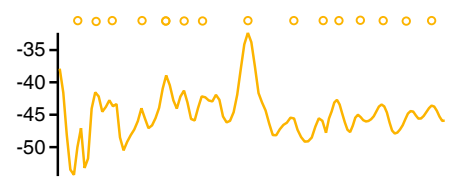

Kohnen - 2015

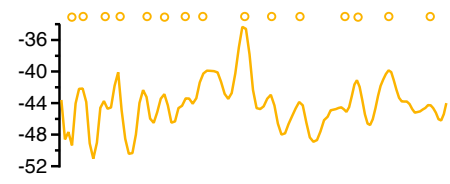

Kohnen - 2015

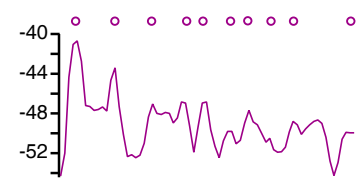

Dome C - 1977

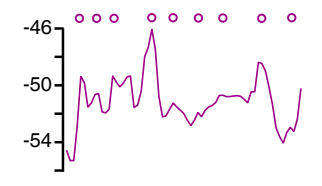

Dome C - 2012
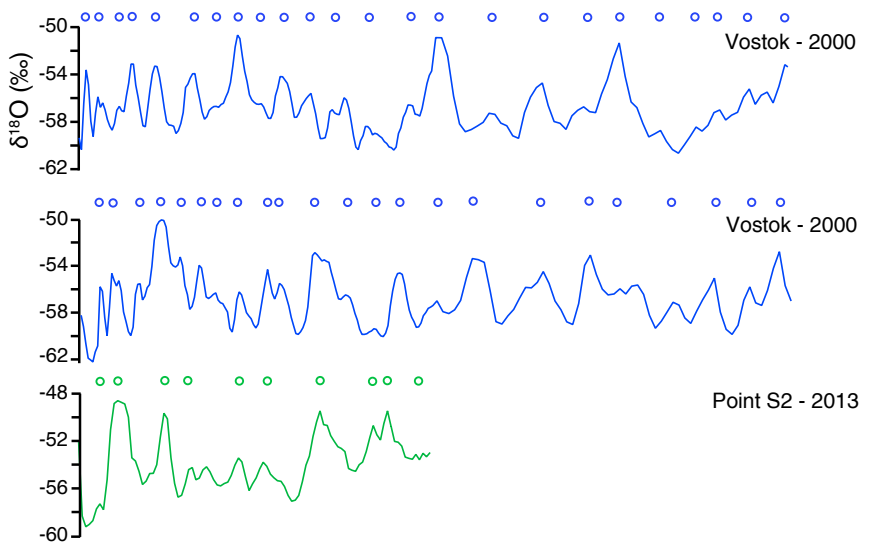

Point S2 - 2013
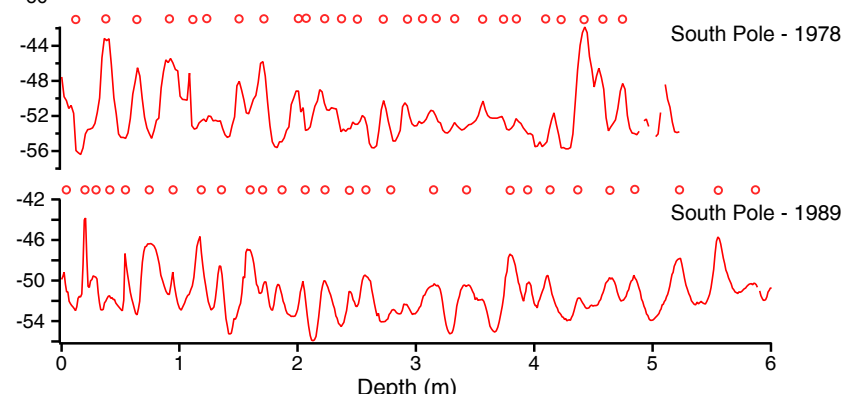

Figure 8. Isotopic composition profiles from 2 pits from Kohnen (Yellow), 2 pits from Dome C (Purple), 2 pits from Vostok (Blue), one pit from S2 (Green) and two pits from South pole (Red) and counting of cycles (circles) for each profile with a threshold of $1.5 \%$ in $\delta^{18} \mathrm{O}$ between the successive local minima/maxima to prevent noise from artificially being counted as cycles. 
The Cryosphere Discuss., doi:10.5194/tc-2016-263, 2016

Manuscript under review for journal The Cryosphere

Published: 17 November 2016

(c) Author(s) 2016. CC-BY 3.0 License.

Table 4. Mean cycle length obtained by manual counting of maxima from the isotopic composition profiles from the pits. Sites are sorted by accumulation in snow equivalent (calculated using an average snow density of $350 \mathrm{~kg} \cdot \mathrm{m}^{-3}$ ).

\begin{tabular}{lcccccc}
\hline Site & $\begin{array}{c}\text { Accumulation } \\
(\mathrm{cm} \text { snow equivalent })\end{array}$ & $\begin{array}{c}\delta^{18} \mathrm{O} \text { cycles } \\
(\mathrm{cm})\end{array}$ & $\begin{array}{c}\delta D \text { cycles } \\
(\mathrm{cm})\end{array}$ & $\begin{array}{c}\text { Number } \\
\text { of pits }\end{array}$ & $\begin{array}{c}\text { Length of } \\
\text { the pits }(\mathrm{m})\end{array}$ & $\begin{array}{c}\text { Finest } \\
\text { Resolution }(\mathrm{cm})\end{array}$ \\
\hline S2 & 6.0 & 24 & 20 & 1 & 2.6 & 3 \\
Vostok & 6.9 & 22 & 22 & 6 & From 2 to 12 & 2 \\
Dome C & 7.7 & 18 & 19 & 4 & From 1 to 3 & 1 \\
Kohnen & 18.3 & 19 & NA & 2 & 3 & 3 \\
South Pole & 19.7 & 20 & 20 & 2 & From 6 to 10 & 1.1 \\
\hline
\end{tabular}

maximum for a limited number of pits with relatively low resolution.

The cycle lengths are longer than expected with the annual accumulation rates for the lowest accumulation sites such as S2, Vostok and Dome C. For these sites, in order to observe the seasonal cycles (with a length of the order of the accumulation between 6 and $7 \mathrm{~cm}$ ), a resolution finer than $3 \mathrm{~cm}$ is necessary to avoid aliasing according to the theorem of Shannon-Nyquist (Nyquist, 1924; Shannon, 1949). Due to the interannual variability of the snow accumulation, the snow isotopic composition will not necessary capture the seasonal variations of temperature and precipitation isotopic composition. The limited resolution of the S2 profile may explain why no seasonal cycle of isotopic composition is visible. In the case of Vostok and Dome C, the vertical resolution of the isotopic composition profile is fine enough to establish the lack of seasonal cycle. Once the resolution is finer than the frequency of Shannon-Nyquist, we do not observe differences in the cycle length with the resolution of the pits. For sites with higher accumulation such as South Pole and Kohnen (around $20 \mathrm{~cm}$ of snow equivalent accumulation), it is expected to be able to identify seasonal cycles in snow isotopic composition (Jouzel et al., 1983). In this case, the observed depth cycles could simply reflect the preservation of seasonal variations in annual layers, as commonly observed in Greenland (Vinther et al., 2010). The profiles are highly variable, exhibiting significant differences in between sites and as well in between pits from a single site, even if sampled the same year, and even for the pits from relatively high accumulation. This can be attributed to the mixture of the potential climate signal and non-climate noise (Fisher et al., 1985; Münch et al., 2016; Laepple et al., 2016).

We observe meaningful differences of the cycle lengths between the top of the pits (typically $20 \mathrm{~cm}$ for the first $3 \mathrm{~m}$ ) and the bottom of the pits (typically $30 \mathrm{~cm} 10 \mathrm{~m}$ deep) for Vostok and South Pole. The amplitude of the cycles is clearly not reduced at the bottom part of the pits compared to the top part as could be expected from diffusion. We note that for Dome C, Kohnen and S2, the profiles are not long enough to evaluate the cycle length-depth dependency. 
The Cryosphere Discuss., doi:10.5194/tc-2016-263, 2016

Manuscript under review for journal The Cryosphere

Published: 17 November 2016

(c) Author(s) 2016. CC-BY 3.0 License.

\section{Discussion}

In this section, we discuss how the results presented above can constrain the different contributions to the snow isotopic composition and the implications for the archival of a climatic isotopic composition signal. First, we evaluate the contribution of precipitation to the surface snow isotopic composition budget. Then, we focus on the post-deposition contribution to the surface snow isotopic composition from exchanges with the atmospheric water vapour. Finally, we discuss how the surface signal is modified during snow burial, and if this affects the archival of the signal. The different processes contributing to the isotopic budget of the snow evaluated in this study are summarised in Fig. 2.

\subsection{Contribution of the precipitation to the surface snow isotopic composition}

Annual records of precipitation isotopic composition at Dome $\mathrm{C}$ highlight a regular cycle in isotopic composition (Fig. 3 and Stenni et al. (2016)) in agreement with the classical modelling of isotopic effects during the distillation along the moisture path and the formation of the snow (Dansgaard, 1964; Jouzel and Merlivat, 1984). As shown in section 3.2, this is not the case for surface snow isotopic composition variations: the seasonal cycle of surface snow isotopic composition is not in phase with the temperature cycle and the precipitation cycle, and the slope between the surface snow isotopic composition and the temperature is reduced compared to the one between the precipitation isotopic composition and the temperature. In this section, we explore whether or not this feature can be explained by (1) the patchiness of the accumulation and the spatial variability due to redistribution and mixing/diffusion in the top centimetres of the snowpack and (2) precipitation intermittency.

First, we evaluate model-data comparison of the climatic signal in the precipitation isotopic composition. Figure 9a presents the isotopic composition - temperature relationship in the dataset of precipitation isotopic composition and computed by the Mixed Cloud Isotopic Model (MCIM). Except in summer (December, January, and February), the MCIM is able to faithfully simulate the precipitation isotopic composition. The simulated relationship between $\delta^{18} O$ and the temperature in the model of $0.95 \% /{ }^{\circ} \mathrm{C}$ (see Table 5) is similar to the one found from the data from the transect between Terra Nova Bay and Dome $\mathrm{C}$ which is not unexpected as these data were used to tune the model (Winkler et al., 2012). For the entire seasonal cycle, we observe for the precipitation isotopic composition a slope below $0.46 \%{ }^{\circ} \mathrm{C}$. Important differences are not unexpected between temporal and spatial slope of precipitation (Ekaykin, 2003; Landais et al., 2012; Touzeau et al., 2016). It is interesting to note here that the winter temporal slope of precipitation isotopic composition $\left(0.76 \%{ }^{\circ} \mathrm{C}\right)$ matches the spatial slope of isotopic composition for the East Antarctic Plateau $\left(0.77 \%{ }^{\circ} \mathrm{C}\right.$ for low isotopic composition area). Here, the low slope of the entire seasonal cycle is associated to the deviation of the summer isotopic composition to a slope of $0.41 \%{ }^{\circ} \mathrm{C}$. One way to explain such a low slope would be to introduce an additional fractionation linked with re-evaporation during the precipitation events which can affect the snow flakes isotopic composition (Koster et al., 1992) and therefore decrease the slope with temperature. This may also result from changes in air masses trajectory and thus, in the Rayleigh distillation. Backtrajectory calculations for the East Antarctic Plateau indicate strong asymmetry of the moisture sources for austral summer and winter (Sodemann and Stohl, 2009; Winkler et al., 2012). Finally, in the MCIM, the condensation temperature is estimated through a linear rela- 
The Cryosphere Discuss., doi:10.5194/tc-2016-263, 2016

Manuscript under review for journal The Cryosphere

Published: 17 November 2016

(c) Author(s) 2016. CC-BY 3.0 License.

tionship with the local surface temperature (Ciais and Jouzel, 1994). The reduced summer temperature inversion at Dome C (Ricaud et al., 2014) is thus not taken into account in the MCIM which could also lead to a reduced slope.

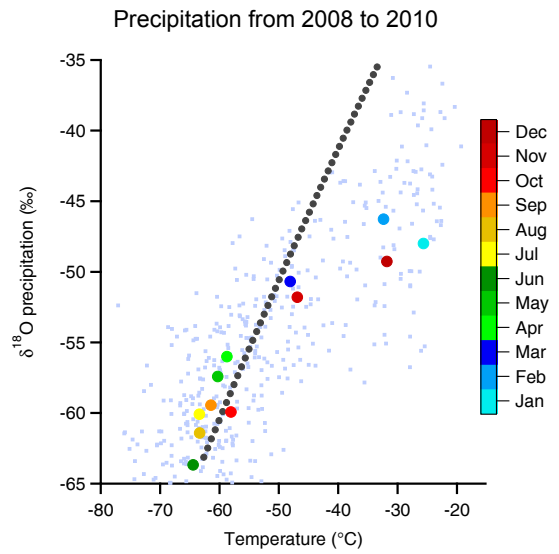

(a)

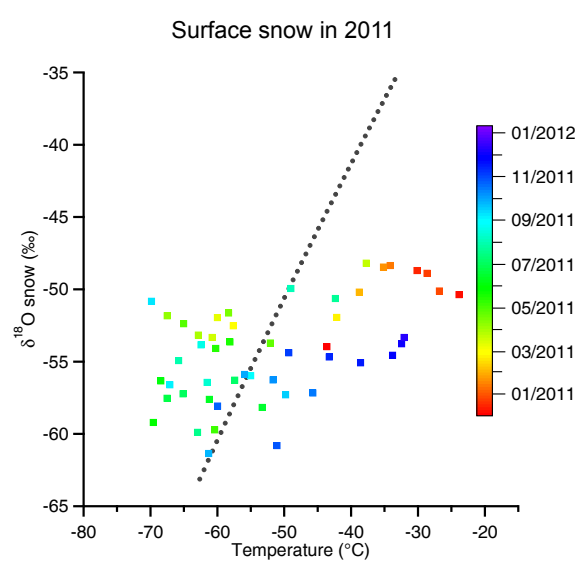

(b)

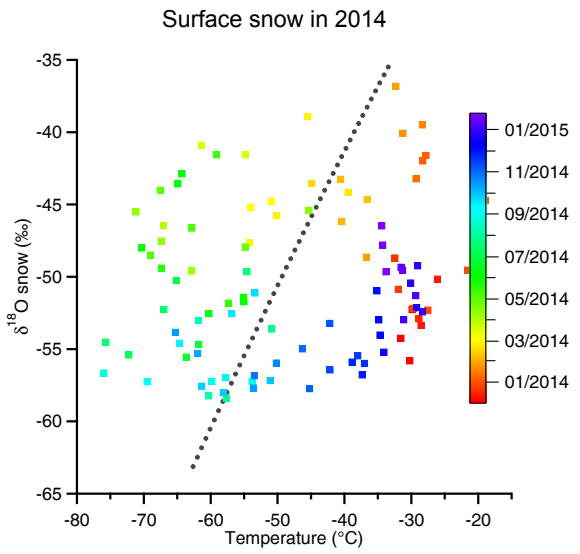

(c)

Figure 9. a) Isotopic composition of precipitation versus 3m temperature from 2008 to 2010 (light blue squares) and mean monthly values over these three years (coloured circles) from our datasets, compared with outputs of the MCIM for the same range of temperature tuned for Dome C (black dots); b) and c) respectively isotopic composition of surface snow in 2011 and 2014 versus 3m temperature.

This indicates that at least during winter, this model is able to predict the value of snow isotopic composition from mixed phase Rayleigh distillation. The tuning of supersaturation for the site of Dome C from Winkler et al. (2012) such as $S=$ $1-0.003 T$, appears valid, at least for winter conditions. This tuning of the supersaturation implies supersaturation up to $115 \%$ in summer conditions at Concordia, in the range of measurements obtained by Genthon et al. (2016).

By contrast, links between temperature and surface snow isotopic composition are more complex (Fig. 4) and we do not observe a linear relationship between surface snow and precipitation isotopic compositions. The range of values spanned by the surface snow isotopic composition cycle is sometime coherent with the precipitation cycle (2014) and sometimes not (2011, 2015; see also Fig. 9). The difference of methods to sample the surface snow through the year does not explain this behaviour as for instance, the same protocol was applied to both 2014 and 2015. The surface snow isotopic composition is compared with the output of the MCIM model (Fig 9). These results confirm that in 2014, the snow isotopic composition spans all the range predicted by the model for this range of temperature, as for precipitation isotopic composition; whereas for 2011 (and 2015, not shown), the surface snow isotopic composition does not rise above $-45 \%$ and does not reflect the enriched summer values. The differences in the maximal summer values between 2014 and 2011 reported here are not linked to the precipitation isotopic composition. Indeed, precipitation events with values of isotopic composition higher than $-40 \%$ have been reported 
The Cryosphere Discuss., doi:10.5194/tc-2016-263, 2016

Manuscript under review for journal The Cryosphere

Published: 17 November 2016

(c) Author(s) 2016. CC-BY 3.0 License.

during all these summers and the isotopic composition of precipitation is in phase with the temperature.

The loop shape of the data for year 2014 (Fig. 9c) suggests that variations of snow isotopic composition are delayed compared to temperature variations. This feature can be attributed to the sampling of $15 \mathrm{~mm}$ of snow which implies mixing of fresh snow with older snow, considering the mean accumulation rate at Dome $\mathrm{C}$ below $8 \mathrm{~cm}$ per year. Nevertheless, the high isotopic compositions of the 2014 summer have been recorded almost simultaneously at the surface and at the sub-surface (section 3.4 and Fig. 7) and do not exhibit the 2 months phasing between change in precipitation $\delta^{18} O$ due to temperature and change in surface snow $\delta^{18} O$.

Table 5. Summary of the isotope temperature relationships observed for the different datasets. For the surface, because of the 2 months shift, the slopes are calculated using the difference between the extrema of isotopic composition and temperature as detailed in section 3.2. For 2012, the summer maxima of isotopic composition were not sampled leading to an underestimation of the slope. For 2011, the dephasing is small enough to perform a linear regression, the result is indicated inside parenthesis. For the precipitation, the vapour and the MCIM output, we ran a linear regression. All the correlations are significant $(p-$ values $<0.05)$.

\begin{tabular}{lccc}
\hline Type of sample & Period & $\begin{array}{c}\text { Slope } \delta^{18} O \text { vs } T \\
\left(\% o{ }^{\circ} \mathrm{C}\right)\end{array}$ & $r^{2}$ \\
\hline \multirow{3}{*}{ Surface } & 2011 & $0.22(0.14)$ & 0.29 \\
& 2012 & $>0.27$ & NA \\
& 2014 & 0.49 & NA \\
\multirow{2}{*}{ Precipitation } & 2015 & 0.27 & NA \\
& All years & 0.46 & 0.65 \\
Vapour & Summer & 0.41 & 0.54 \\
\hline \multirow{2}{*}{ MCIM } & Winter & 0.76 & 0.56 \\
\hline \multirow{2}{*}{ Transect to Dome C } & Summer 2015 & 0.46 & 0.26 \\
\hline
\end{tabular}

During an episode of precipitation, for "high-accumulation" sites, the isotopic composition of the precipitation is stored in the surface snow, and contributes to archiving the local temperature signal through the isotopic fractionation during the formation of the snowflakes (Jouzel and Merlivat, 1984). For a low accumulation site such as Dome C, each precipitation event is not necessarily captured by the surface snow isotopic composition because the snow deposition is patchy and strongly dependant of the surface roughness (Groot Zwaaftink et al., 2013; Libois et al., 2014; Picard et al., 2016a). In Fig. 4, we also present the isotopic composition with ERA-interim snowfall product to illustrate this patchiness of the snow deposition at the event scale. If ERA-interim does not provide reliable quantitative estimates of the amount of snowfall on the East Antarctic Plateau, it has been shown to be relevant to predict at least the temporality of most snowfall events at Dome C (Libois et al., 2015). At Dome 
The Cryosphere Discuss., doi:10.5194/tc-2016-263, 2016

Manuscript under review for journal The Cryosphere

Published: 17 November 2016

(c) Author(s) 2016. CC-BY 3.0 License.

C, as described by Touzeau et al. (2016), we can see that warm winter precipitation events are often associated with significant variations of surface snow isotopic composition (up to 5\%o), nevertheless, we still observe a large number of precipitation events not associated with any variations of surface snow isotopic composition.

At the seasonal scale, the patchiness of the accumulation cannot explain why the surface snow does not systematically record the precipitation signal, and thus, why we observe missing summer values in the surface snow isotopic composition. Indeed, in 2014, we obtained several time-series of surface snow isotopic composition and at the seasonal scale, we observe a strong agreement between the time-series. Additionally, for the NIVO and the SUNITEDC campaigns, the samples were randomly taken, thus, they should not be systematically affected by the erasing of the precipitation signal in the surface snow isotopic composition.

Finally, while the slope between precipitation isotopic composition versus temperature is also stable over the different years, it is not the case for the surface snow. The slope between surface snow $\delta^{18} \mathrm{O}$ and temperature of $2014\left(0.49 \% o /{ }^{\circ} \mathrm{C}\right)$ is similar to the one observed in precipitation $\left(0.46 \%{ }^{\circ} \mathrm{C}\right)$, as shown in Table 5, indicating a probable link. The slopes of 2011 and 2015 are much lower. In the case of 2015, we observe a rather low cumulative precipitation amount (see Fig. 4) which could explain the small values of summer $\delta^{18} O$, but it is not the case for 2011. Because both the average values of $\delta^{18} O$ and the slopes of surface snow $\delta^{18} O$ against temperature differ from the ones of precipitation in 2011 and 2015, the lack of a summer signal in 2011 and 2015 surface snow isotopic composition cannot only be due to the intermittency of precipitation, and requires to involve post-deposition processes.

\subsection{Contribution of sublimation/condensation cycles to the surface snow isotopic composition}

Another possible factor affecting the surface snow isotopic composition is post-deposition, in particular exchange with atmospheric water vapour associated with metamorphism. At the seasonal scale, the significance of the contribution of the post-deposition is supported by the comparison of the isotopic composition of the surface snow to the grain index (see Fig. 4).

The high values of grain index in the summer can be attributed to intense metamorphism (Picard et al., 2012; Libois et al., 2015), the rise usually starts during the first week of December. Rapid falls of the grain index result from important precipitation events and the input of small snow grains from precipitation. Finally, the slow decrease during winter is explained by the accumulation of new small snow flakes by precipitation onto the coarse grains formed during the summer. Winter metamorphism is too slow to impact the snow structure.

For the surface snow isotopic composition variations, two features of interests are visible in Fig. 4. We observe inter-annual variability of the summer surface snow isotopic composition. This inter-annual variability seems to be directly related to the strength of the metamorphism: we obtain a strong negative correlation between the amplitude of the grain-index increase in summer and the maximum $\delta^{18} O$. The summer increase of $\delta^{18} O$ seems to be very sensitive to the date at which the intense 
The Cryosphere Discuss., doi:10.5194/tc-2016-263, 2016

Manuscript under review for journal The Cryosphere

Published: 17 November 2016

(c) Author(s) 2016. CC-BY 3.0 License.

summer metamorphism starts. The large values of $\delta^{18} O$ observed in 2014 (and maybe for the year 2012, but the maximum of $\delta^{18} O$ was reached before the sampling started) are associated with a small and delayed increase of grain index (in both case, the main increase of grain index happens after the 15th of January, whereas for normal years, it starts the first week of December). This delayed start of the metamorphism enables the surface snow to capture the enriched precipitation isotopic composition

5 of summer. Second, in winter, we observe a mixing of new income of precipitation on the top of already deposited snow as illustrated by the slow decrease of the $\delta^{18} O$ during the entire winter. This is similar to what is observed for the grain index. By contrast, there is no apparent relationship between precipitation isotopic composition and grain index from 2008 to 2011 (see Fig. 3).

This indicates the importance of metamorphism in the formation of the surface snow isotopic signal as a post-deposition process. If Picard et al. (2012) highlight a direct link between the summer intensity of metamorphism and the integrated amount of accumulation over the summer, we do not observe a link with the summer amplitude of the surface snow isotopic composition variations (even though more years are necessary to attest the lack of link). In order to disentangle the different fractionation processes involved in the metamorphism, we evaluate the formation of this $\delta^{18} O$ signal during snow metamorphism by studying in parallel the vapour and the snow isotopic composition at the diurnal time scale in summer.

Metamorphism can affect the surface snow isotopic composition through exchanges of water molecules between the snow and the moisture: either the atmospheric water vapour or the interstitial air water vapour. Here, we focus on the coarsening of the grains due to the exchanges with the atmospheric vapour under the influence of the diurnal cycle of temperature. Exchanges between snow and atmospheric vapour during sublimation/condensation cycles can significantly affect the surface snow isotopic composition. Indeed, it has been shown in Greenland that the mass balance was set by both sublimation/condensation cycles and synoptic storm events (Steen-Larsen et al., 2014; Berkelhammer et al., 2016). In between precipitation events, moisture exchanges significantly affect the snow isotopic composition over several days and a parallel evolution of the snow and vapour isotopic compositions is observed in NEEM (Steen-Larsen et al., 2014). Similar observations have been made in Kohnen in Antarctica by Ritter et al. (2016) during summer 2013/2014. Dome C is a colder site than NEEM or Kohnen, thus we expect a less efficient metamorphism. Still, because the accumulation rate at Dome C $\left(2.3 \mathrm{~cm} . \mathrm{yr}^{-1}\right.$ w.e. $)$ is lower than at NEEM (20 cm.yr $r^{-1}$ w.e. $)$ and than at Kohnen $\left(6.4 \mathrm{~cm}_{.} \mathrm{yr}^{-1}\right.$ w.e. $)$, we expect to observe a stronger relative impact of the interplay between vapour and snow.

At Dome $\mathrm{C}$, we also observe that the surface snow isotopic composition is significantly affected by the exchanges of molecules with the vapour in between precipitation events. However, at the diurnal scale (see section 3.3), no parallel evolution is observed in snow and vapour isotopic compositions contrasting with results from NEEM and Kohnen. Our observations are coherent with exchanges in a closed box system: the vapour is enriched in heavy isotopes while snow is depleted during frost deposition events. This is consistent with equilibrium fractionation in a closed box where the vapour isotopic composition is predicted by equilibrium fractionation with the snow (Casado et al., 2016b). We attribute the difference of behaviour compared 
The Cryosphere Discuss., doi:10.5194/tc-2016-263, 2016

Manuscript under review for journal The Cryosphere

Published: 17 November 2016

(c) Author(s) 2016. CC-BY 3.0 License.

to Kohnen (Ritter et al., 2016) and NEEM (Steen-Larsen et al., 2014) to the position of the station on the top of a dome. Indeed, at Dome $\mathrm{C}$, the weakness of the katabatic winds decreases the renewal of air masses long enough for the exchanges with the snow to be detected. At Kohnen and NEEM, stronger winds are observed leading to a more efficient renewal of air masses able to exchange with the surface. Preliminary results from back trajectory analyses indicate that most of the air masses arriving at Dome $\mathrm{C}$ have been loaded with moisture within the last $50 \mathrm{~km}$ before Dome C. It is important to note that the humidity content at Dome $\mathrm{C}$ is lower than at Kohnen and NEEM, resulting in a smaller reservoir of water vapour with which the snow can exchange. Despite these low humidity levels, a significant impact of the sublimation/condensation cycles on the snow isotopic composition is observed. Similar studies measuring isotopic composition of vapour and snow at sites with similar temperatures but larger wind speeds (such as at Vostok), could provide more robust insights on the impact of wind on renewal of air masses compared to humidity levels. This study relies on one event of attested frost deposition and the monitoring of more events is necessary to be able to quantitatively evaluate the fractionation processes involved.

\section{Conclusions}

In this study, we explored the post-deposition processes affecting the archival of water isotopic composition from precipitation to the snow pack for low accumulation sites of the East Antarctic Plateau. We focused in particular oin the exchanges between the vapour and the snow occurring during snow metamorphism and on how the accumulation and the burial of the snow layers affect the isotopic composition signals found in the precipitation, the surface snow and the buried snow. We combined a comprehensive dataset from precipitation, surface snow, buried snow and atmospheric vapour isotopic compositions to assess the impact of theses two post-deposition processes compared to the original climatic signal captured by precipitation isotopic composition. Figure 10 presents the histogram of the isotopic composition of the precipitation, the surface snow, in 2011 and in 2014, and in the snow pits. Additionally, we present the average value of each distribution as well with the standard deviation of the distributions.

The distribution of isotopic composition in the precipitation is much larger than the distribution of the surface snow isotopic composition. As discussed in section 3.2, a large range of depleted precipitation isotopic composition, mostly observed in winter, are not represented in the surface snow isotopic composition. Below the surface, apart from a few isolated enriched samples with $\delta^{18} O$ values above $-45 \%$, the distribution of isotopic composition is even narrower than at the surface (both the red and the green points). The narrowing of the distributions of the isotopic composition from the surface to the buried snow (Fig. 10) could be explained by isotopic diffusion in the snow (Langway, 1970; Johnsen, 1977; Johnsen et al., 2000; Gkinis et al., 2014). These large differences of the signals in the isotopic composition of the precipitation, the surface snow and the buried snow document the various processes involved in the archival of the climatic signal in the snow isotopic composition on the East Antarctic Plateau. 
The Cryosphere Discuss., doi:10.5194/tc-2016-263, 2016

Manuscript under review for journal The Cryosphere

Published: 17 November 2016

(c) Author(s) 2016. CC-BY 3.0 License.

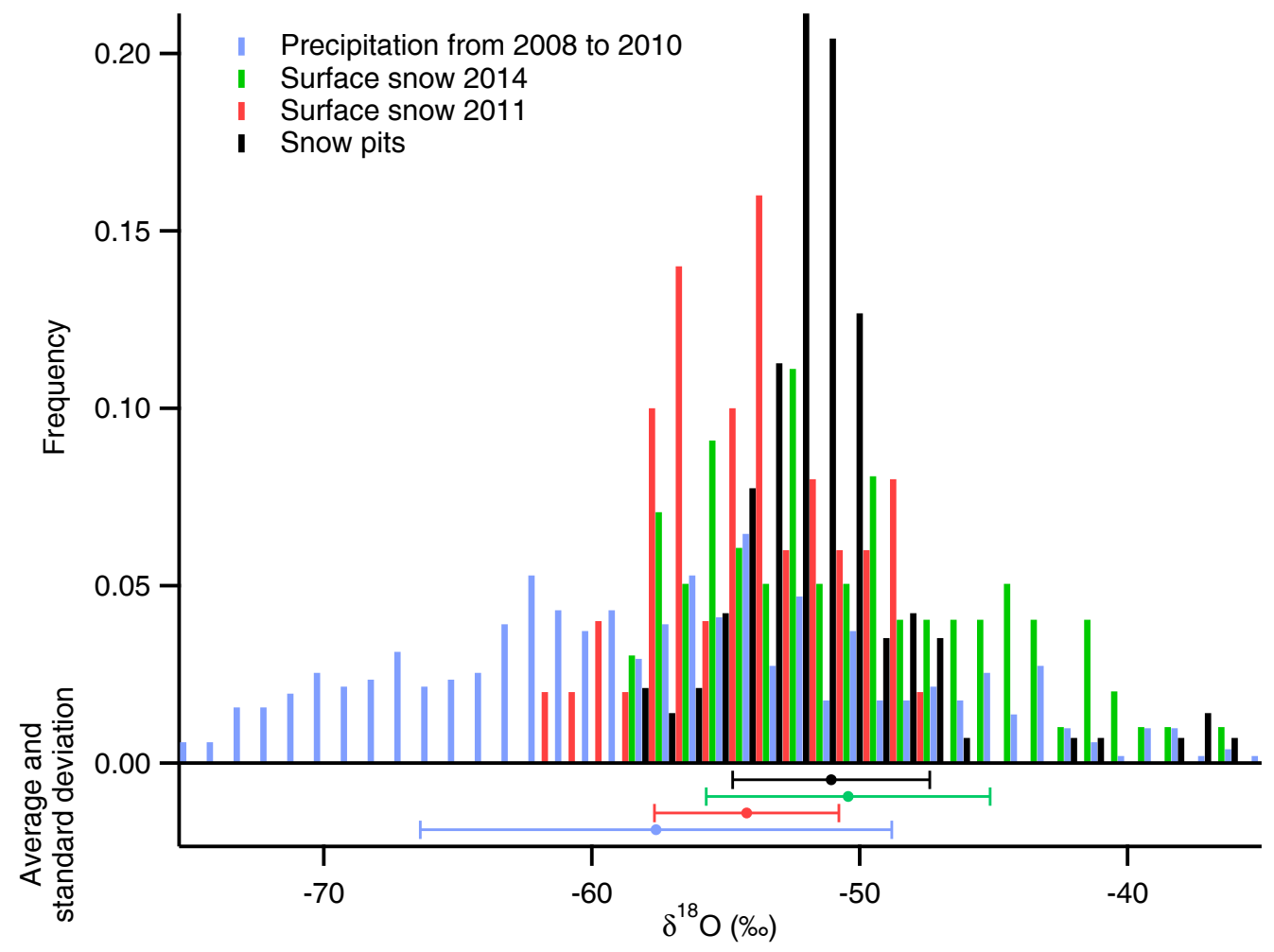

Figure 10. Top: Histogram of the isotopic composition at Dome C of precipitation (blue), of surface snow in 2014 (green) and in 2011 (red) and of four snow pits stacked together (black). Bottom: dots: average value for each distribution and, error bars: standard deviation of the ensemble.

First, we evaluated at the seasonal scale the different contributions to the snow isotopic composition between the precipitation on one hand and the exchanges with the atmosphere on the other hand. We compared the seasonal variations of precipitation and surface snow isotopic composition. We observed an inter-annual variability in the seasonal cycle of surface snow isotopic composition which deviates from the regular seasonal cycle of precipitation isotopic composition. The large differences between the average isotopic composition of surface snow and precipitation might indicate a significant impact of post-deposition processes in the site of Dome C. This is supported by a clear link between the surface snow isotopic composition and both the intensity and the temporality of summer metamorphism. Furthermore, post depositions effects are not limited to summer: in winter, a large range of very depleted precipitation isotopic compositions is not observed at all in the surface snow isotopic composition.

Second, we focused on the impact of the exchanges between the vapour and the snow at the diurnal scale. With simultaneous hourly measurements of atmospheric vapour and surface snow isotopic composition, we evaluated one part of the metamor- 
The Cryosphere Discuss., doi:10.5194/tc-2016-263, 2016

Manuscript under review for journal The Cryosphere

Published: 17 November 2016

(c) Author(s) 2016. CC-BY 3.0 License.

phism component: exchanges between atmosphere and snow pack through sublimation/condensation cycles. We showed that for a place like Dome $\mathrm{C}$ with low wind speed, it is possible to have a closed system where the vapour is enriched while the snow is depleted. This one case is the first field observation of a potentially closed system in Antarctica and differs from NEEM and Kohnen where the vapour and the snow evolve in parallel, probably due to stronger katabatic winds which renew the vapour reservoir.

Finally, we evaluated the evolution of the isotopic signal while the snow is being buried. We highlighted that there are recurrent $20 \mathrm{~cm}$ cycles in the isotopic composition profiles in the snow pack in five sites from East Antarctica: Dome C, Kohnen, S2, South Pole and Vostok. This finding raises doubts on the interpretation of high resolution variations from such sites. A detailed investigations of these cycles is out of the scope of this study, but will ,be presented in a follow up publication (Laepple et al., in prep).

Despite combining different types of data (precipitation, vapour surface snow and snow pits isotopic compositions) from five different sites, some elements are still lacking to robustly quantify the different contributions to the snow isotopic composition budget due to diverse limitations: the lack of winter measurement of the vapour isotopic composition prevented us to evaluate the complete annual cycle of exchanges between vapour and snow, especially considering that the atmospheric boundary layer has a different structure in winter than in summer; the differences of resolution and of depth of the snow pits depending of the sites limited the interpretation of the cycles through robust spectral methods; and finally the small number of locations where precipitation and surface snow were sampled all year long on the East Antarctic Plateau (only Dome C) hindered a generalisation of the results for the link between metamorphism and surface snow isotopic composition to the entire East Antarctic Plateau. This study was limited to the impact of post-deposition processes on the first order of variations of isotopic composition ( $\delta$ values). Still, excesses ( $d$ - excess and ${ }^{17} \mathrm{O}$ - excess) are expected to provide further insights to understand processes due to their different sensitivity to kinetic fractionation (Casado et al., 2016a). This will be explored in another independent study.

Our study covers different contributions to the snow isotopic signal during the archival in Antarctica and demonstrates that the climatic signal initially acquired in the precipitation isotopic composition is not necessarily stored in the surface snow and in the buried snow. These results yield for a more quantitative evaluation of the impact of post-deposition processes on the isotopic composition, in particular of snow metamorphism and interstitial diffusion; through controlled laboratory experiments, field studies and using snow models. The link between snow isotopic composition and temperature in Polar ice cores appear strongly affected by all these post-deposition processes at the intra to inter-annual scale. The interpretation of ice core records is today most limited by the lack of understanding of these post-deposition processes. Progress in this direction is needed to strengthen a physically based interpretation of water stable isotope records for quantitative paleoclimate reconstructions. 
The Cryosphere Discuss., doi:10.5194/tc-2016-263, 2016

Manuscript under review for journal The Cryosphere

Published: 17 November 2016

(c) Author(s) 2016. CC-BY 3.0 License.

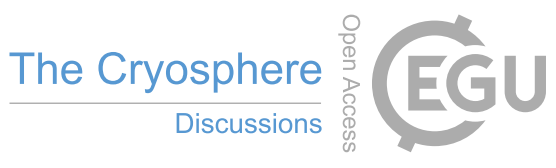

(c) (i)

Acknowledgements. The research leading to these results has received funding from the European Research Council under the European Union's Seventh Framework Programme (FP7/2007-2013) / RC grant agreement number 306045. We acknowledge the programs NIVO and GLACIO and all the IPEV staff that made this campaign possible, LGGE and LIPHY for providing logistic advice and support, PNRA-PREREC project for the 2014 surface snow data at Concordia station. 
The Cryosphere Discuss., doi:10.5194/tc-2016-263, 2016

Manuscript under review for journal The Cryosphere

Published: 17 November 2016

(c) Author(s) 2016. CC-BY 3.0 License.

\section{References}

Alley, R. B.: Densification and recrystallization of firn at Dome C, East Antarctica, 1980.

Altnau, S., Schlosser, E., Isaksson, E., and Divine, D.: Climatic signals from 76 shallow firn cores in Dronning Maud Land, East Antarctica, The Cryosphere, 9, 925-944, 2015.

5 Baroni, M., Bard, E., Petit, J. R., Magand, O., and Bourlès, D.: Volcanic and solar activity, and atmospheric circulation influences on cosmogenic 10Be fallout at Vostok and Concordia (Antarctica) over the last 60years, Geochimica et Cosmochimica Acta, 75, 7132-7145, doi:10.1016/j.gca.2011.09.002, 2011.

Berkelhammer, M., Noone, D. C., Steen-Larsen, H. C., Bailey, A., Cox, C. J., O’Neill, M. S., Schneider, D., Steffen, K., and White, J. W. C.: Surface-atmosphere decoupling limits accumulation at Summit, Greenland, Science Advances, 2, 2016.

Casado, M., Cauquoin, A., Landais, A., Israel, D., Orsi, A., Pangui, E., Landsberg, J., Kerstel, E., Prie, F., and Doussin, J.-F.: Experimental determination and theoretical framework of kinetic fractionation at the water vapour-ice interface at low temperature, Geochimica et Cosmochimica Acta, 174, 54-69, doi:http://dx.doi.org/10.1016/j.gca.2015.11.009, 2016a.

Casado, M., Landais, A., Masson-Delmotte, V., Genthon, C., Kerstel, E., Kassi, S., Arnaud, L., Picard, G., Prie, F., Cattani, O., Steen-Larsen, H. C., Vignon, E., and Cermak, P.: Continuous measurements of isotopic composition of water vapour on the East Antarctic Plateau, Atmospheric Chemistry and Physics, 16, 8521-8538, doi:10.5194/acp-16-8521-2016, 2016b.

Casey, K. A., Fudge, T. J., Neumann, T. A., Steig, E. J., Cavitte, M. G. P., and Blankenship, D. D.: The 1500 m South Pole ice core: recovering a 40 ka environmental record, Annals of Glaciology, 55, 137-146, 2014.

Ciais, P. and Jouzel, J.: Deuterium and oxygen 18 in precipitation: Isotopic model, including mixed cloud processes, Journal of Geophysical Research: Atmospheres, 99, 16 793-16 803, doi:10.1029/94JD00412, 1994.

20 Dansgaard, W.: Stable isotopes in precipitation, Tellus, 16, 436-468, doi:10.1111/j.2153-3490.1964.tb00181.x, 1964.

Delaygue, G., Jouzel, J., Masson, V., Koster, R. D., and Bard, E.: Validity of the isotopic thermometer in central Antarctica: limited impact of glacial precipitation seasonality and moisture origin, Geophysical Research Letters, 27, 2677-2680, 2000.

Ekaykin, A.: Meteorological regime of central Antarctica and its role in the formation of isotope composition of snow thickness, Ph.D. thesis, Geography Faculty of Saint Petersbourg, 2003.

Ekaykin, A. A. and Lipenkov, V. Y.: Formation of the ice core isotopic composition, Physics of ice core records, Low Temperature Science, 68, 299-314, 2009.

Ekaykin, A. A., Lipenkov, V. Y., Barkov, N. I., Petit, J. R., and Masson-Delmotte, V.: Spatial and temporal variability in isotope composition of recent snow in the vicinity of Vostok station, Antarctica: implications for ice-core record interpretation, Annals of Glaciology, 35, 181-186, doi:10.3189/172756402781816726, 2002.

30 Ekaykin, A. A., Lipenkov, V. Y., Kuzmina, I. N., Petit, J. R., Masson-Delmotte, V., and Johnsen, S. J.: The changes in isotope composition and accumulation of snow at Vostok station, East Antarctica, over the past 200 years, Annals of Glaciology, 39, 569-575, doi:10.3189/172756404781814348, 2004.

Ekaykin, A. A., Kozachek, A. V., Lipenkov, V. Y., and Shibaev, Y. A.: Multiple climate shifts in the Southern Hemisphere over the past three centuries based on central Antarctic snow pits and core studies, Annals of Glaciology, 55, 259-266, 2014.

EPICA: Eight glacial cycles from an Antarctic ice core, Nature, 429, 623-628, http://dx.doi.org/10.1038/nature02599, 2004.

EPICA: One-to-one coupling of glacial climate variability in Greenland and Antarctica, Nature, 444, 195-198, http://dx.doi.org/10.1038/ nature 05301, 2006. 
The Cryosphere Discuss., doi:10.5194/tc-2016-263, 2016

Manuscript under review for journal The Cryosphere

Published: 17 November 2016

(c) Author(s) 2016. CC-BY 3.0 License.

Fisher, D. A., Reeh, N., and Clausen, H. B.: Stratigraphic noise in time series derived from ice cores, Ann. Glaciol, 7, 76-83, 1985.

Frezzotti, M., Urbini, S., Proposito, M., Scarchilli, C., and Gandolfi, S.: Spatial and temporal variability of surface mass balance near Talos Dome, East Antarctica, Journal of Geophysical Research: Earth Surface, 112, doi:10.1029/2006JF000638, 2007.

Fujita, K. and Abe, O.: Stable isotopes in daily precipitation at Dome Fuji, East Antarctica, Geophysical Research Letters, 33, doi:10.1029/2006GL026936, 2006.

Genthon, C., Six, D., Favier, V., Lazzara, M., and Keller, L.: Atmospheric Temperature Measurement Biases on the Antarctic Plateau, Journal of Atmospheric and Oceanic Technology, 28, 1598-1605, doi:10.1175/jtech-d-11-00095.1, 2011.

Genthon, C., Six, D., Gallée, H., Grigioni, P., and Pellegrini, A.: Two years of atmospheric boundary layer observations on a 45-m tower at Dome $\mathrm{C}$ on the Antarctic plateau, Journal of Geophysical Research: Atmospheres, 118, 3218-3232, doi:10.1002/jgrd.50128, http: //dx.doi.org/10.1002/jgrd.50128, 2013.

Genthon, C., Six, D., Scarchilli, C., Ciardini, V., and Frezzotti, M.: Meteorological and snow accumulation gradients across Dome C, East Antarctic plateau, International Journal of Climatology, pp. n/a-n/a, doi:10.1002/joc.4362, http://dx.doi.org/10.1002/joc.4362, 2015.

Genthon, C., Piard, L., Vignon, E., Madeleine, J.-B., Casado, M., and Gallée, H.: Atmospheric moisture supersaturation in the near-surface atmosphere at Dome C, antarctic plateau, Atmos. Chem. Phys. Discuss., 2016, 1-37, doi:10.5194/acp-2016-670, 2016.

Gkinis, V., Simonsen, S. B., Buchardt, S. L., White, J. W. C., and Vinther, B. M.: Water isotope diffusion rates from the NorthGRIP ice core for the last 16,000 years-Glaciological and paleoclimatic implications, Earth and Planetary Science Letters, 405, 132-141, 2014.

Goff, J. A. and Gratch, S.: Thermodynamic properties of moist air, ASHVE Trans, 51, 125-158, 1945.

Groot Zwaaftink, C. D., Cagnati, A., Crepaz, A., Fierz, C., Macelloni, G., Valt, M., and Lehning, M.: Event-driven deposition of snow on the Antarctic Plateau: analyzing field measurements with SNOWPACK, The Cryosphere, 7, 333-347, 2013.

Johnsen, S. J.: Stable isotope homogenization of polar firn and ice, Isotopes and impurities in snow and ice, 1, 1977.

Johnsen, S. J., Clausen, H. B., Cuffey, K. M., Hoffmann, G., and Creyts, T. T.: Diffusion of stable isotopes in polar firn and ice: the isotope effect in firn diffusion, Physics of ice core records, pp. 121-140, 2000.

Jouzel, J. and Masson-Delmotte, V.: Paleoclimates: what do we learn from deep ice cores?, Wiley Interdisciplinary Reviews: Climate Change, 1, 654-669, doi:10.1002/wcc.72, http://dx.doi.org/10.1002/wcc.72, 2010.

Jouzel, J. and Merlivat, L.: Deuterium and oxygen 18 in precipitation: Modeling of the isotopic effects during snow formation, Journal of Geophysical Research: Atmospheres, 89, 11 749-11757, doi:10.1029/JD089iD07p11749, 1984.

Jouzel, J., Merlivat, L., Petit, J. R., and Lorius, C.: Climatic information over the last century deduced from a detailed isotopic record in the south pole snow, Journal of Geophysical Research: Oceans, 88, 2693-2703, doi:10.1029/JC088iC04p02693, http://dx.doi.org/10.1029/ JC088iC04p02693, 1983.

30 Koster, R. D., Jouzel, J., Suozzo, R. J., and Russell, G. L.: Origin of July Antarctic precipitation and its influence on deuterium content: a GCM analysis, Climate Dynamics, 7, 195-203, doi:10.1007/BF00206861, http://dx.doi.org/10.1007/BF00206861, 1992.

Krinner, G., Genthon, C., and Jouzel, J.: GCM analysis of local influences on ice core delta signals, Geophysical Research Letters, 24, 2825-2828, doi:10.1029/97gl52891, 1997.

Küttel, M., Steig, E. J., Ding, Q., Monaghan, A. J., and Battisti, D. S.: Seasonal climate information preserved in West Antarctic ice core water isotopes: relationships to temperature, large-scale circulation, and sea ice, Climate Dynamics, 39, 1841-1857, doi:10.1007/s00382012-1460-7, http://dx.doi.org/10.1007/s00382-012-1460-7, 2012.

Laepple, T., Hörhold, M., Münch, T., Freitag, J., Wegner, A., and Kipfstuhl, S.: Layering of surface snow and firn at Kohnen Station, Antarctica: Noise or seasonal signal?, Journal of Geophysical Research: Earth Surface, 2016. 
The Cryosphere Discuss., doi:10.5194/tc-2016-263, 2016

Manuscript under review for journal The Cryosphere

Published: 17 November 2016

(c) Author(s) 2016. CC-BY 3.0 License.

Landais, A., Barkan, E., and Luz, B.: Record of $\delta 180$ and 17O-excess in ice from Vostok Antarctica during the last 150,000 years, Geophysical Research Letters, 35, L02 709, doi:10.1029/2007GL032096, 2008.

Landais, A., Ekaykin, A., Barkan, E., Winkler, R., and Luz, B.: Seasonal variations of 17O-excess and d-excess in snow precipitation at Vostok station, East Antarctica, Journal of Glaciology, 58, 725-733, doi:10.3189/2012JoG11J237, 2012.

5 Langway, C. C.: Stratigraphic analysis of a deep ice core from Greenland, vol. 125, Geological Society of America, 1970.

Lazzara, M. A., Keller, L. M., Markle, T., and Gallagher, J.: Fifty-year Amundsen-Scott South Pole station surface climatology, Atmospheric Research, 118, 240-259, doi:http://dx.doi.org/10.1016/j.atmosres.2012.06.027, 2012.

Libois, Q., Picard, G., Arnaud, L., Morin, S., and Brun, E.: Modeling the impact of snow drift on the decameter-scale variability of snow properties on the Antarctic Plateau, Journal of Geophysical Research: Atmospheres, 119, 11,611-662,681, doi:10.1002/2014JD022361, http://dx.doi.org/10.1002/2014JD022361, 2014.

Libois, Q., Picard, G., Arnaud, L., Dumont, M., Lafaysse, M., Morin, S., and Lefebvre, E.: Summertime evolution of snow specific surface area close to the surface on the Antarctic Plateau, The Cryosphere, 9, 2383-2398, doi:10.5194/tc-9-2383-2015, http://www. the-cryosphere.net/9/2383/2015/http://www.the-cryosphere.net/9/2383/2015/tc-9-2383-2015.pdf, 2015.

Lorius, C., Merlivat, L., and Hagemann, R.: Variation in the mean deuterium content of precipitations in Antarctica, Journal of Geophysical Research, 74, 7027-7031, doi:10.1029/JC074i028p07027, 1969.

Masson-Delmotte, V., Delmotte, M., Morgan, V., Etheridge, D., Van Ommen, T., Tartarin, S., and Hoffmann, G.: Recent southern Indian Ocean climate variability inferred from a Law Dome ice core: New insights for the interpretation of coastal Antarctic isotopic records, Climate Dynamics, 21, 153-166, 2003.

Morgan, V. I.: An oxygen isotope—climate record from the Law Dome, Antarctica, Climatic Change, 7, 415-426, 1985.

Münch, T., Kipfstuhl, S., Freitag, J., Meyer, H., and Laepple, T.: Regional climate signal vs. local noise: a two-dimensional view of water isotopes in Antarctic firn at Kohnen Station, Dronning Maud Land, Climate of the Past, 12, 1565-1581, doi:10.5194/cp-12-1565-2016, 2016.

NEEM community members, N.: Eemian interglacial reconstructed from a Greenland folded ice core, Nature, 493, 489-494, http://dx.doi. org/10.1038/nature11789, 2013.

Nicolas, J. P. and Bromwich, D. H.: New Reconstruction of Antarctic Near-Surface Temperatures: Multidecadal Trends and Reliability of Global Reanalyses, Journal of Climate, 27, 8070-8093, doi:doi:10.1175/JCLI-D-13-00733.1, 2014.

North Greenland Ice Core Project members: High-resolution record of Northern Hemisphere climate extending into the last interglacial period, Nature, 431, 147-151, http://dx.doi.org/10.1038/nature02805, 2004.

Nyquist, H.: Certain Factors Affecting Telegraph Speed1, Bell System technical journal, 3, 324-346, 1924.

Oerter, H., Wilhelms, F., Jung-Rothenhäusler, F., Göktas, F., Miller, H., Graf, W., and Sommer, S.: Accumulation rates in Dronning Maud Land, Antarctica, as revealed by dielectric-profiling measurements of shallow firn cores, Annals of Glaciology, 30, 27-34, 2000.

Petit, J. R., Jouzel, J., Pourchet, M., and Merlivat, L.: A detailed study of snow accumulation and stable isotope content in Dome C (Antarctica), Journal of Geophysical Research: Oceans, 87, 4301-4308, doi:10.1029/JC087iC06p04301, 1982.

Petit, R. J., Raynaud, D., Basile, I., Chappellaz, J., Ritz, C., Delmotte, M., Legrand, M., Lorius, C., Pe, L., Petit, J. R., Jouzel, J., Raynaud, D., Barkov, N. I., Barnola, J. M., Basile, I., Bender, M., Chappellaz, J., Davis, M., Delaygue, G., Delmotte, M., Kotlyakov, V. M., Legrand, M., Lipenkov, V. Y., Lorius, C., Pepin, L., Ritz, C., Saltzman, E., and Stievenard, M.: Climate and atmospheric history of the past 420,000 years from the Vostok ice core, Antarctica, Nature, 399, 429-436, http://dx.doi.org/10.1038/20859, 1999. 
The Cryosphere Discuss., doi:10.5194/tc-2016-263, 2016

Manuscript under review for journal The Cryosphere

Published: 17 November 2016

(c) Author(s) 2016. CC-BY 3.0 License.

Picard, G., Domine, F., Krinner, G., Arnaud, L., and Lefebvre, E.: Inhibition of the positive snow-albedo feedback by precipitation in interior Antarctica, Nature Climate Change, 2, 795-798, 2012.

Picard, G., Arnaud, L., Panel, J.-M., and Morin, S.: Design of a scanning laser meter for monitoring the spatio-temporal evolution of snow depth and its application in the Alps and in Antarctica, The Cryosphere, 10, 1495-1511, doi:10.5194/tc-10-1495-2016, 2016a.

5 Picard, G., Libois, Q., Arnaud, L., Verin, G., and Dumont, M.: Development and calibration of an automatic spectral albedometer to estimate near-surface snow SSA time series, The Cryosphere, 10, 1297-1316, doi:10.5194/tc-10-1297-2016, $2016 \mathrm{~b}$.

Pol, K., Masson-Delmotte, V., Cattani, O., Debret, M., Falourd, S., Jouzel, J., Landais, A., Minster, B., Mudelsee, M., Schulz, M., and Stenni, B.: Climate variability features of the last interglacial in the East Antarctic EPICA Dome C ice core, Geophysical Research Letters, 41, 4004-4012, doi:10.1002/2014GL059561, 2014.

Ricaud, P., Carminati, F., Courcoux, Y., Pellegrini, A., Attié, J.-L., El Amraoui, L., Abida, R., Genthon, C., August, T., and Warner, J.: Statistical analyses and correlation between tropospheric temperature and humidity at Dome C, Antarctica, Antarctic Science, 26, 290308, 2014.

Ritter, F., Steen-Larsen, H. C., Werner, M., Masson-Delmotte, V., Orsi, A., Behrens, M., Birnbaum, G., Freitag, J., Risi, C., and Kipfstuhl, S.: Isotopic exchange on the diurnal scale between near-surface snow and lower atmospheric water vapor at Kohnen station, East Antarctica, The Cryosphere Discuss., 2016, 1-35, doi:10.5194/tc-2016-4, 2016.

Schlosser, E., Reijmer, C., Oerter, H., and Graf, W.: The influence of precipitation origin on the d18O-T relationship at Neumayer station, Ekströmisen, Antarctica, Annals of Glaciology, 39, 41-48, 2004.

Schmidt, G. A., LeGrande, A. N., and Hoffmann, G.: Water isotope expressions of intrinsic and forced variability in a coupled ocean/atmosphere model, Journal of Geophysical Research: Atmospheres, 112, 2007.

Schneebeli, M. and Sokratov, S. A.: Tomography of temperature gradient metamorphism of snow and associated changes in heat conductivity, Hydrological Processes, 18, 3655-3665, doi:10.1002/hyp.5800, 2004.

Shannon, C. E.: Communication in the presence of noise, Proceedings of the IRE, 37, 10-21, 1949.

Sime, L. C., Wolff, E. W., Oliver, K. I. C., and Tindall, J. C.: Evidence for warmer interglacials in East Antarctic ice cores, Nature, 462, 342-345, http://dx.doi.org/10.1038/nature08564, 2009

Sodemann, H. and Stohl, A.: Asymmetries in the moisture origin of Antarctic precipitation, Geophysical research letters, $36,2009$.

Sokratov, S. A. and Golubev, V. N.: Snow isotopic content change by sublimation, Journal of Glaciology, 55, 823-828, doi:10.3189/002214309790152456, 2009.

Steen-Larsen, H. C., Masson-Delmotte, V., Hirabayashi, M., Winkler, R., Satow, K., Prié, F., Bayou, N., Brun, E., Cuffey, K. M., and DahlJensen, D.: What controls the isotopic composition of Greenland surface snow?, Climate of the Past, 10, 377-392, 2014.

Stenni, B., Scarchilli, C., Masson-Delmotte, V., Schlosser, E., Ciardini, V., Dreossi, G., Grigioni, P., Bonazza, M., Cagnati, A., Frosini, D., Karlicek, D., Risi, C., Udisti, R., and Valt, M.: Three-year monitoring of stable isotopes of precipitation at Concordia Station, East Antarctica, The Cryosphere, 2016, 1-30, doi:10.5194/tc-2016-142, 2016.

Touzeau, A., Landais, A., Stenni, B., Uemura, R., Fukui, K., Fujita, S., Guilbaud, S., Ekaykin, A., Casado, M., Barkan, E., Luz, B., Magand, O., Teste, G., Le Meur, E., Baroni, M., Savarino, J., Bourgeois, I., and Risi, C.: Acquisition of isotopic composition for surface snow in East Antarctica and the links to climatic parameters, The Cryosphere, 10, 837-852, doi:10.5194/tc-10-837-2016, 2016.

Town, M. S., Warren, S. G., Walden, V. P., and Waddington, E. D.: Effect of atmospheric water vapor on modification of stable isotopes in near-surface snow on ice sheets, Journal of Geophysical Research: Atmospheres, 113, doi:10.1029/2008JD009852, 2008. 
The Cryosphere Discuss., doi:10.5194/tc-2016-263, 2016

Manuscript under review for journal The Cryosphere

Published: 17 November 2016

(c) Author(s) 2016. CC-BY 3.0 License.

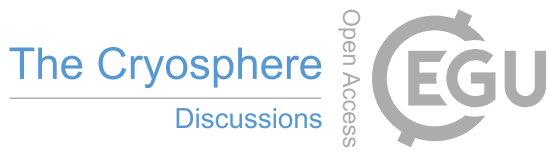

(c) (1)

van As, D., van den Broeke, M. R., and Helsen, M. M.: Strong-wind events and their impact on the near-surface climate at Kohnen Station on the Antarctic Plateau, Antarctic Science, 19, 507-519, doi:10.1017/S095410200700065X, 2007.

Van Den Broeke, M. R.: The semi-annual oscillation and Antarctic climate. Part 1: Influence on near surface temperatures (1957-79), Antarctic Science, 10, 175-183, 1998.

5 Vimeux, F., Masson, V., Jouzel, J., Stievenard, M., and Petit, J. R.: Glacial-interglacial changes in ocean surface conditions in the Southern Hemisphere, Nature, 398, 410-413, http://dx.doi.org/10.1038/18860, 1999.

Vinther, B. M., Jones, P. D., Briffa, K. R., Clausen, H. B., Andersen, K. K., Dahl-Jensen, D., and Johnsen, S. J.: Climatic signals in multiple highly resolved stable isotope records from Greenland, Quaternary Science Reviews, 29, 522-538, doi:http://dx.doi.org/10.1016/j.quascirev.2009.11.002, 2010.

Waddington, E. D., Steig, E. J., and Neumann, T. A.: Using characteristic times to assess whether stable isotopes in polar snow can be reversibly deposited, Annals of Glaciology, 35, 118-124, doi:10.3189/172756402781817004, 2002.

Wendler, G. and Kodama, Y.: On the climate of Dome C, Antarctica, in relation to its geographical setting, J. Climatol, 4, 495-508, 1984.

Whillans, I. M. and Grootes, P. M.: Isotopic diffusion in cold snow and firn, Journal of Geophysical Research: Atmospheres, 90, 3910-3918, doi:10.1029/JD090iD02p03910, 1985.

15 Whitlow, S., Mayewski, P. A., and Dibb, J. E.: A comparison of major chemical species seasonal concentration and accumulation at the South Pole and Summit, Greenland, Atmospheric Environment. Part A. General Topics, 26, 2045-2054, 1992.

Winkler, R.: Triple-oxygen isotopic composition of meteoric waters: 17 O-excess a new tracer of the hydrological cycle, 2012.

Winkler, R., Landais, A., Sodemann, H., Dümbgen, L., Prié, F., Masson-Delmotte, V., Stenni, B., and Jouzel, J.: Deglaciation records of 17O-excess in East Antarctica: reliable reconstruction of oceanic normalized relative humidity from coastal sites, Clim. Past, 8, 1-16, doi:10.5194/cp-8-1-2012, 2012. 